\section{SOCIEDAD DE RESPONSABILIDAD LIMITADA}

\section{BREVE ESTUDIO COMPARATIVO DE LEGISLACIONES LATINOAMERICANAS}

\section{Osvaldo J. Stratta}

Catedrático titular de Derecho Comercial en la Facultad de Ciencias Jun (Santa Fé, Republica Argentina).

Sumario: 1. - Generalidades. Importancia de las sociedades de responsabilidad limitada. - 2. - Características essenciales de las mismas. - 3. - Reglas de constitución y publicidad. - 4. - Núnero'de socios. - 5. - Objeto. - 6. - Capital: a) responsabilidad limitada a las aportaciones; b) suscripción e integración; c) monto; d) mitada a las aportaciones, - Razón social o denominación. - 8. otras prescripciones. - 7. - fiscalización de la sociedade: a) ColectiGobierno, administración y fiscalización de la sociedade: a) - Diso-

vidad de socios; b) Administradores; c) Fiscalización. -
lución. 10. - Derecho supletorio. - 11. - Conclusiones.

1 - Generalidades. Importancia de las sociedades de responsabilidad limitada. La sociedad de responsabilidad limitada contituye una forma de empresa que se ha impuesto definitivamente en tituye una forma de empresa que societario en los negocios de cael campo merc

Su aparición puede calificarse, con la relatividad de estas apreciaciones, de reciente, pues adoptando como antecedente más antiguo ciaciones a lo sumo al año 1862 el del derecho inglés, podaciones orgánicas sobre la materia, hemos de y refiriéndo-nos a legislaciones organicas sobre la materia, hemos de tomar como punto inicial la ley alemana de 1892, a la cual suceden
otras, con intervalos más o menos largos y ya en el siglo actual $\left(^{1}\right)$.

(1) Así, sin próposito exhaustivo, podemos citar las leyes de Portugal (sancionada en el año 1901), de Austra (1esde 1923), Bulgaria (1924), Francia (1925), Liechtens. tein (1926), Bélgica (1935), Suiza (1936), Italia en el nuevo código civil (sancionado en 1942); China, de acuerdo con lo manifestado por Escarra, las in método comparativo, sociedades del año 1946 (Jean Esearra, El Berecho - sec. doct. ps. 9.52-9.57). En parte de algunos paises formados con territorios del ex imperio austrohnugaro rigio la ley austríaca, que originó alli leyes o proyectos de caracter gecion expressa sôbre socie
En el derecho latinoamericano, - que es el que nos interessa particularmente en este breve estudio - citamos, por orden cronológico la ley brasileña No 3708 , del 10 de enero de 1919, cuyo título es "Sociedades por cuotas" con el subtítulo "Regula la constitución de las sociedades por cuotas de responsabilidad limitada"; la ley cubana de 17 de abril de 1929 , publicada el 26 del mismo mes y año, sobre sociedades limitadas; la sancionada en la República Argentina el 29 de septiembre de 1932 y con vigencia desde el 8 de octubre del mismo año, bajo el número 11645 y con el título "sociedades de responsabilidad limitada"; el decreto-ley dictado el 26 de abril de 1933, en el Uruguay $\left({ }^{2}\right)$; la ley mexicana, del 4 de agosto de 1934 , conocida como "Ley general de sociedades mercantiles", dentro de la cual (capítulo IV, arts. 58 a 86), se contempla el tipo social de referencia $\left({ }^{3}\right)$; el código civil de Perú, vigente por la ley 8305 y promulgada el 30 de agosto de 1936 , en cuyo libro $5^{\circ}$, sección quinta, título XIV relativo al contrato de sociedad, se legisla - arts. 1725 a 1730 - sobre las sociedades civiles de responsabilidad limitada; la ley colombiana N. $^{\circ}$ 127 del 24 de noviembre de 1937, sobre compañías de responsabilidad limitada; la ley boliviana del 12 de marzo de 1941; y el decreto ley N.o 10268, del 29 de diciembre del mismo año, de Paraguay ( ${ }^{2}$ ). Puede citarse además, el proyecto de código de comercio de la Re-

dades de responsabilidad limitada, por via indireta (ver $\mathrm{k}$. Gay de Montellá,Código de 政 La Ley, t. 46 - Buenos Aires, 1947 - p. 909; sôbre la posibilidad de adpitarles el mitimos, en razón de la brevedad de este estudio, a la obra de Feine, Las sociedades de responsabilidad limitada - Madrid, 1930 - ps. 5 a 11. mos en el curso de este trabajo aquélla denominación igual que a los demśs estatutos legales. (3) Señalemos que en México existe, además, una ley "sobre "Sociedades de res.
ponsabilidad limitada de interés público". publicada en el "Diário Oficial" el 31 d ponsabilidad limitada de interés público", publicada en el "Diario Oficial" el 31 de aglidad limitada de interés público sólo se constituirá cuando se trate de actividades do interés público y particular conjuntamente, a juicio de la Secretaría de Economía Nacional En los artículos siguientes dispone que la sociedade solo se constituira mediante auto-
rización del Ejecutivo Federal $y$ con el trámite que deja establecido, inclusive para la inscripcíón en el Registro Público de Comercio; debe constituirse como de capital variable existe limíte suerior; el importe de una parte social no podrá exceder del veinticinco por ciento del capital de la sociedad; el fondo de reserva debe ser del veinte por ciento por un Consejo de un Consejo de Vigilancia integrado por dos sócios como mínimo; los derechos de la minoria deben quedar asegurados en el contrato social para las designaciones prealudidas y en todo caso la minoria que represente un veinticinco por ciento del capital nombrar funcionamiento de la sociedad; y dispone que salvo lo expresamente prescrito por dicha ley, la sociedad se regirá por las disposiciones generales de la ley de sociedades mercan

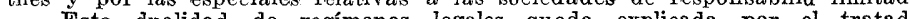
J. Rodríguez $\vee$ Rodríguez en estos términos: "En las relaciones económicas son frecuen tes las agrupaciones de empresas con objeto de limitar la concurrencia, organizar la producentes formas económicas $y$ jurídicas, y reciben varios nombres en la préstica internacional, en la que se habla de Trust, Konzern, Kartel, etc. Estas formas de organización economica no siempre responden a tendencias monopolísticas, sino que frecuente 
pública Dominicana, preparado por el professor J. H. Ducoudray y por disposición gubernamental, en cuyo libro segundo, primera parte, título III, (sobre las sociedades mercantiles, se reconoce la existencia de sociedades prealudidas (art. 51, inc, $4 .^{\circ}$ ), reglamentadas en capítulo V.

Los guarismos estadísticos traducen en todas partes la máxima aceptación que esta classe ed sociedades ha tenido $\left({ }^{4}\right)$, tanto en la constitución de nuevas compañías, como en la transformación de anteriores, especialmente sociedades anónimas y de nombre colectivo, que adoptaron esta nueva forma $\left({ }^{5}\right)$.

Frente a dichas comprobaciones numéricas y a la entusiasta acogida que han tenido en la órbita de la vida comercial, consideramos injustificadas las críticas que se le han hecho, no muchas por cierto. Una de las más recientes es la de Ripert, quien afirma entre otras cosas: "Es malo permitir en condiciones tan fáciles la limitación de responsabilidad, La moralidad comercial no ha ganado con esta creación. Las bancarrotas son múltiples sin alcanzar a las personas pues la sociedade solamente es la fallida. La sociedad de responsabilidad limitada encuentra por otra parte poco crédito. Frecuentemente el gerente debe obligarse personalmente hacia los acreedores; él pierde entonces la ventaja a no ser más que'un gerente y asume de hecho, el papel de un comanditado" $\left({ }^{6}\right)$.

mente, se nos presentan como exigencias de las organización económica para poner fin a la anarquía que pueda resultar de una competencia desenfrenada, o de la falta forma de sociedades civiles o mercantiles, y aún la de simples asociaciones en participación. Una de las formas preferidas para ello ha sido la Sociedad de Responsabilidad Limitada, que se presta especialmente para esta misión por la posibilidad de que su bilidad que le es propia y por las prestaciones suplementarias y accesorias que son peculiares de esta forma de sociedad mercantil. Para utilizar las múltiples ventajas de la Sociedad de Responsabilidad Limitada en la organización de los grandes intereses de la economía nacional el legislador mexicano dictó la ley del 28 de agosto de 1934
(D. O. dia 31 sobre Sociedades de Responsabilidad Limitada de Inters Público y Capital Variable). (Ourso de Derecho Mercantil, México - 1947, t. I--ps. 169-170). Con esta síntesis del régimen legal aludido y la opinión transcripta dejamos completado el tópico, con la advertencia de que al referirnos a la legislación mexicana en (4) Demonstración de ello en lo que respecta a la República Argentina son las siguientes cifras, relativas solamente al número de contratos (por razones de brevedad,

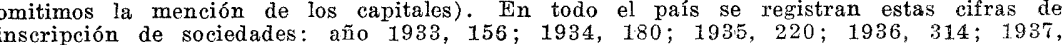
$378 ; 1938,464 ; 1939,555 ; 1941,781 ; 1942,1124 ; 1943,1316 ; 1944,1558 ; 1945$, $1995 ; 1946$, 2929. La progresión se observa en particular, con respecto a la ciudad de Buenos Aires, con estas cifras: en 1943, se inseribieron 773 contratos; en 1944, 1024; en 1945, 1178; en 1946, 1649; en 1947, 221. En 1944,66 ; 1945,88 ; 1946, 100, 1947, 126 y en 1948, 195. Es decir, que ya sea en conjunto, o ya en medios comerciales de mayor o menor importancia el movimiento
ascendente es uniforme; y es menester añadir que, a través de estadisticas de otros páses, que no transcribimos por no extenḋernos, la comprobación es la misma.

(5) Puede señalarse, desde ahora, que la transformación de las sociedades existentes en conpañias de responsabilidad limitada, está contemplada ex̀presamente en varias leyes:

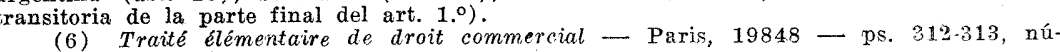
(6) Traite
Esta apreciación crítica, pese a provenir de tan reputado autor, no es exacta. La limitación de la responsabilidad es una necesidad sentida por el comercio: prueba de ello la difusión de las sociedades anónimas, y de las que nos ocupan; de la limitación aludida no puede derivarse un problema de moralidad, pues la deshonestidad es cuestión de los individuos, más que de las formas, y puede campear en cualquier tipo y género de empresa; el timo y el fraude aparecen como posibles en cualquier clase de negocios, y se pueden evitar con una adecuada reglamentación legal; y los casos que subsistan pese a ella no bastan para desechar una creación que presenta singulares ventajas; no es exacto en todas partes el aumento de las falencias y, además, no se pueden imputar siempre a la forma adoptada, y el hecho de que no alcance a los socios es precisamente una ventaja de esta sociedad; finalmente, lo relativo a la conceșión del crédito implica una cuestión de hecho que en cada supuesto depende de muchos factores - capital, moralidad, prosperidad de los negocios - y no es distinto del que se presenta en las sociedades anónimas que también limitan su responsabilidad a la masa social.

2 - Características esenciales. Para poder sintetizar las características esenciales de las sociedades de referencia, resulta necesario señalar las ideas básicas que presidieron la creación de las mismas. A ese fin nada mejor que transcribir la resolución del Congreso de Cámaras de Comercio alemanas de 1888: "1. ${ }^{\circ}$ Los medios eomerciales e industriales reconocen que existe una urgente necesidad de completar el derecho vigente, con la introducción de nuevas formas de sociedad para las empresas privadas; $20^{\circ}$ Es posible satisfacer esta necesidad con una ley que cree sociedades sobre la base de individualidades y capitales, y en las cuales la participación de los asociados sería dividida en partes y su responsabilidad limitada" $\left({ }^{7}\right)$. En otros términos, se palpaba la necesidad de que fuese factible la constitución de una sociedad que sin excluir la intervención personal y directa de los socios (característica en las sociedades colectivas), permitiera limitar la responsabilidad de éstos a la suma aportada, como en las sociedades anónimas, pero diferenciándose de las mismas en cuanto a que los aportes se materializarían en cuotas o partes sociales y no en acciones, con las consiguientes diferencias en punto a transmisibilidad.

De lo expuesto se sigue - anotemos de paso - que el nombre más comunmente adoptado por las legislaciones y también por la doctrina - o sea el de sociedades o compañias de responsabilidad limitada, o simplemente sociedades limitadas - no tiene rigor lógico, pues también se limita la responsabilidad en las anónimas y aún en las sociedades en comandita en lo que se refiere a los socios comandi-

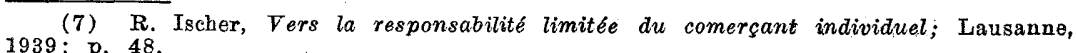


tarios. De mayor precisión conceptual resulta en el derecho latino americano la ley brasileña, que se refiere a las "sociedades por cuotas ¿de responsabilidade limitada", en cuanto señala una característica que las diferencia de las anónimas. y que es la de la representación del capital social en cuotas, según queda visto. Empero, como el uso se inclina prevalentemente en favor de la primera de las denominaciones, utilizada en el título del trabajo, nos decidimos a mantener la misma, que representa un contenido de común inteligencia.

Creemos dejar señaladas las dos características esenciales de las sociedades del tipo que estudiamos: limitación de la responsabilidad de los socios al monto de los aportes ( $\sin$ excluir la probabilidad de aportación de cuotas suplementarias, previstas por algunas leyes), :salvo casos de excepción que contemplan las legislaciones especialmente cuando no están debidamente integrados aquéllos; y prohibición de representar el capital por acciones, lo cual elimina - a veces por texto expreso - la posibilidad de buscar los capitales por medio de subscripción pública $\mathrm{y}$, sobre todo, veda la posibilidad de la transmisión del aporte en la forma en que las acciones se negocian; debe materializarse el capital en cuotas, cesibles en forma limitada, con los requisitos que fijan los diversos estatutos legales.

Otros rasgos que se han señalado como esenciales no lo son, en nuestra opinión, como la de la personalidad distinta de la de los socios, pues en muchas legislaciones, incluso la argentina, es carácter común a todos los entes sociales, y en las de tipo más restringido se adjudica cuando menos a las anónimas, por lo que no puede servir para diferenciación; la intervención de los socios en la marcha de la sociedad, que puede o no presentarse como ineludible (según se consagre o no a los socios como administradores natos), se relaciona mejor con el problema de la naturaleza, en cuanto si se trata de sociedades de capital o de personas, y atañe también a la forma de ejercerse la administración.

Establecidos los lineamientos del tema, con las generalidades que anteceden, trataremos de concretar una síntesis no ya de las notas esenciales, naturales o comunes de las sociedades tratadas, sino de la forma en que reglamentan las leyes americanas los puntos más interesantes, no todos, porque ésta seria materia de mucha extención $\left(^{8}\right)$.

3 - Reglas de constitución y publicidad. No son acordes las opiniones doctrinarias y las soluciones legales sobre las exigencias de

(8) Para justificar desde ahora este estudio, citaremos palabras del tratadista Roberto Goldschmidt, las cuales, auque referidas a las sociedades anónimas, se aplican perfectamente aquí: "Tanto desde el runto de vista científico como práctico, es de sumo cias para el ordemaniento jurídico del propio país, tanto por a aplicación consecuencias para el ordemaniento jurídico del propio país, tanto por la aplicación como por la
reforma del derecho positivo" (Problemas juridicos de la sociedad anónima ; Buenos Aires -1946, p. 2). forma para la constitución. Algunos tratadistas prefieren la escritura pública por las garantías que ofrece la intervención notarial, y otros, para facilitar la formación, y incluso para no encarecerla en el caso de pequeñas sociedades, admiten también la posibilidad de hacerlo por documento privado.

Por nuestra parte preferimos a la segunda solución - admisión de ambas clases de documentos constitutivos - que es la de las leyes argentinas (art. $4 .^{\circ}$ ), uruguaya (art. $5 .^{\circ}$ ) y brasileña, ésta por remisión a normas generales (art. $2 .^{\circ}$ de la ley 302 del cód. de comércio), porque entendemos que con la redacción de un contrato en que se observen las prescripciones legales y se refleje la voluntad de los interesados, y la inscripción posterior en el Registro de Comercio, las garantías son prácticamente las mismas que en el acto notarial. Lo contrario - exigencia de escritura pública - disponen las leyes bolivianas (art. 2..$^{\circ}$ ), colombiana (art. $2 .^{\circ}$ ) cubana (art. $1 .^{\circ}$ apartado b), chilena (art. $2 .^{\circ}$ ) paraguaya (art. $4 .^{\circ}$ ), y también la peruana (art. 1689 del cód. civil) y mexicana (art. $5 .^{\circ}$ de la ley de sociedades), pero en estas dos últimas es por aplicación de normas comunes a las sociedades en general.

En lo tocante a requisitos que debe observar el contrato, la ley argentina es minuciosa, pues los enumera en siete incisos del art. 4..$^{\circ}$ de parecida prolijidad son la cubana (art. $10^{\circ}$ apartado b), paraguaya $\left(\operatorname{art} .4^{\circ}\right.$ ), y uruguaya (art. $5 .{ }^{\circ}$ ). La ley colombiana (art. $2^{\circ}$ ) se refiere a las enunciaciones generales en materia de sociedades y a las específicas sobre la limitación de la responsabilidad, declarándose también el íntegro pago de los aportes y la estimación de los bienes aportados en especie; la chilena, a las enunciaciones comunes a toda sociedad y a la declaración de que la responsabilidad se limita a los aportes (art. $2 .^{\circ}$ ). La ley brasileña se remite (art. $2 .^{\circ}$ ) a los requisitos generales para todas las sociedades comerciales (especificados en el art. 302 del cód. de comercio), además de las declaraciones concernientes a la limitación de la responsabilidad; la ley boliviana se refiere en su art. $20^{\circ}$ a las disposicioens del art. 321 del cód. mercantil donde están contenidas las exigencias comunes a todas las sociedades; y nada dice la ley mexicana, por lo que deben entenderse vigentes las disposiociones generales en materia de sociedad, lo mismo que en el caso de la ley civil peruana.

Inscripción en el Registro de Comercio o Mercantil - según la denominación local - exigen expresamente las leyes argentinas (art 5..$^{\circ}$, cubana (art. 1. ${ }^{\circ}$ apartado b), uruguaya (art. 6..$^{\circ}$ brasileña (art. $2 .^{\circ}$ que remite al 301 del Código), colombiana (art. $3 .^{\circ}$, donde exige la inscripción de un extracto de la escritura social), chilena (art. $3 .^{\circ}$, con la especial mención de que debe hacerse íntegramente, a diferencia de la anterior), y paraguaya (art. $5 .^{\circ}$ ); esta última contiene 17 - R. D. $1 .^{\circ}$ Vol 
sobre las demás, la innovación de fijar el procedimiento de la inscripción, que debe ser ordenada por el Juez de Comercio, con intervención del Agente Fiscal en lo Civil y Comercial de turno. En la ley de México nada se expresa, pero resulta de indudable aplicación el art. 19 del cód. de comercio y el art. 2. ${ }^{\circ}$ de la ley general de sociedades de dicho país, que establecen la aludida exigencia. $\left.{ }^{9}\right)$. Y la ley boliviana, además de la inscripción referida, establece la de todas las operaciones de crédito que realice la sociedad (art. 17).

Formalidades aún mayores exigen varias leyes con la publicación del contrato social: la argentina (art. $5^{\circ}$ ) la impone por el plazo de cinco días en el Boletín Oficial o periódico de la localidad, si no hubiere aquél, para que pueda la sociedad funcionar como tal y bajo la severa sanción - como ante la falta de inscripción - de que los socios incurran frente a terceiros en responsabilidad solidaria e ilimitada (art. 6. ${ }^{\circ}$ ); la ley uruguaya establece la publicación de un extracto por diez días y en dos períódicos, y con análogo efecto y sanción que en la anterior, extendiéndose esta última - la responsabilidad ilimitada y solidaria - a los administradores (art. 68); también tiene exigencias de publicación en el Diario Oficial la ley chilena (art. $3^{\circ}{ }^{\circ}$ ), so pena de nulidad entre los socios y responsabilidad solidaria de los socios fundadores para todas las obligaciones contraídas en interés de la sociedad; la ley boliviana determina que se publicará "en um periódico de crédito de la capital de departamento en la que tengan su sede (las sociedades), el tenor de la escritura social" (art. 17), entendiéndose que ello implica una condición constitutiva porque recién "después de diez días de haber hecho esta publicación las sociedades podrán comenzar sus actividades"; la ley paraguaya que, si es procedente la inscripción en el Registro Público de Comercio, el juez ordenará y "dispondrá la publicación por ocho veces, en la Gaceta Oficial y otro diario, com preferencia en un diario local, de un extrato del contrato construtivo..." con los datos que se consignam en la misma disposición $\left(\right.$ art. $\left.5 .^{\circ}\right)$

4 - Número de socios. Parecería obvio señalar que el número mínimo debe ser de dos, incluso porque lo exigen expresa o implícitamente las definiciones doctrinarias y aún las legales (10). Pero no es así cuando menos por un par de razones: a) La posibilidad de que pudiera exigirse un número mayor, supuesto que se presenta categóricamente con la ley boliviana, la cual establece para la constitución o subsistencia de la sociedad, un número de tres socios. b) Porque así

(9) Conf. J. Rodríguez y Rodríguez, obra citada - p. 160 (10) Caso del art. 282 del código de comercio argentino: "La compañía o siciedsd: se alegaría la duda que se mantiene en torno a la subsistencia de la sociedad con un solo socio (11).

Queda dicho que en la ley boliviana aparece expresa la exigencia del mínimo de tres socios, tanto para la existencia como para la subsistencia de la sociedad, previsión que es acertada al incluir este segundo aspecto. La ley cubana requiere el número de dos socios para la constitución (art $1^{\circ}$ apartado a). En las demás debe sobreentenderse igual requisito de un mínimo de dos miembros, por aplicación de principios generales, tanto para la constitución de la sociedad como para su posterior subsistencia ${ }^{12}$; ; la reducción a uno, es para nosotros, un supuesto de disolución ineludible. $Y$ contra esto no puede arguirse la necesidad de que se contemple esa posibilidad, pues ello daría lugar a la instauración jurídica de las empresas individuales de responsabilidad limitada, que permitiría también remediar la anomalía de la existencia de sociedades - tanto anónimas como de responsabilidad limitada - en que el verdadero interesado es uno sólo, que aporta realmente los capitales, buscando así limitar su responsabilidad, y los otros son meros prestanombres.

En general, las legislaciones establecen expresamente un máximo de socios. Se ha justificado esta limitación diciéndose que "debe ser

(11) En la jurispŕrudencia argentina se registra un caso en el cual la justicia en lo comercial de la ciudade de Buenos Aires consideró que si la ley no exige un número mínimo de socios para constituir una sociedad de responsabilidad limitada,
bastando, por conseguiente, dos firmantes, y si ese número inicial puede disminuirse durante la vida de la sociedad por la adquisición que haga un miembro de las cuotas del otro u otros, el ente subsiste. Y se cita luego a Karl Heinsheinmer (en su obra Derecho Mercantil, p. 180), en estos conceptos: "...puede ocurrir que todas las par
ticipaciones queden en manos del mismo propietario. La sociedad limitada no se disuelve

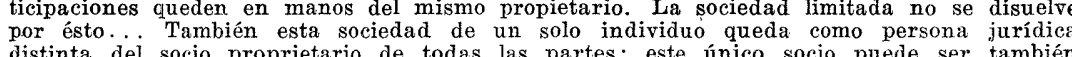
, fallo del 22 de setiembre de 1943, y segunda instancia, del 30 de octubre del min

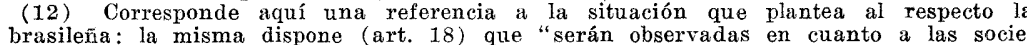
dades por cuotas de responsabilidad limitada, en lo que no fuese reglado por el estatuto socia en a parte apicable, las disposicioas la ley sobre sociedades anonimas. N. 2627 del 21 de septiembre de 1940), se ha entendido - y ya con el texto originario del código brasileño, que tenía el número minimo de socios - que puede la sociedad

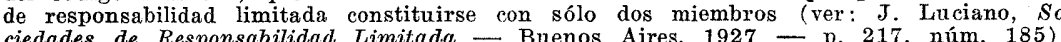
esto puede explicarse con la consideración que hace el tratadista brasileño Waldemar Ferreira de que las disposiciones sobre sociedades anónimas son subsidiarias de la voluntad de las partes contratantes, cuando pueden ser aplicables, pero no subsidiaria
de la voluntad del legislador, que elaboró las sociedades por cuotas, y el concepto del mismo autor de que "son sociedades solidarias o de nombre colectivo, de responsabilidad limitada de los cuotistas a la importancia total del capital social. No son como al principio se supuso, sociedades anónimas simplificadas". (Compendio de sociedades mercantiles, Rio de Janeiro - $1940, \mathrm{p}$. 145); de lo que resulta que aproximandose las socie
dades colectivas, no regiría el precepto de sociedades anónimas respecto del número de socios.

De la existencia de éstas y parecidas dificultades doctrinarias se deduce que no es ocioso establecer el número mínimo de socios, en dos, o a lo sumo tres, como lo hace la
boliviana: nunca en número más elevado porque tal exigencia sería incompatible con empresas pequeñas cual son muchas de responsabilidad limitada, o aún para las gran des que desean formarse por muy pocos socios y que no logren reunir el mínimo que siete en la brasileña, ete.). 
una sociedade de pocos socios ligados por la relación de confianza recíproca, de manera que en ella el recto funcionamento administrativo, garantizado por esta relación de confianza, no necesite la complicada organización de la sociedade anónima" (13).

Dentro de las legislaciones americanas podemos señalar que la ley argentina y uruguaya prescriben un máximo de veinte socios (arts. $8 .^{\circ}$ y $7 .^{\circ}$ respectivamente), con excepción del caso en que se incorporen empleados como socios, con posterioridad a la constitución, situación en que se permite un número adicional de cinco; también tiene un máximo de veinticinco socios las leyes boliviana (art. $3 .^{\circ}$ ), mexicana (art. 61. ${ }^{\circ}$ ) y paraguaya (art. 11); es asimismo categórica la ley de Colombia, al estabelecer en su art. 5. "El número de socios en las compañías que tratan esta ley no podrán exceder de veinte. Si de hecho se constituyese en contravención a esta disposición, habrá nulidad absoluta entre los socios y en caso de aumento una vez establecidos, se producirá su disolución". El límite fijado por la ley chilena es el más amplio, pues alcanza a cincuenta (art. $20^{\circ}$ ), y es el más restringido el de la legislación de Cuba (art. $1 .^{\circ}$, apartado a), que lo fija en diez.

En definitiva, salvo la legislación brasileña y la peruana, todas las aquí estudiadas se pronuncian en sentido afirmativo en cuanto al establecimento de um número de asociados.

5 - Objeto. Se observa en algunas leyes la tendencia a ampliar el objeto de estas sociedades con la inclusión de los negocios civiles o de extender a ellos, cuando son realizados bajo la forma de compañía de responsabilidad limitada, la ley mercantil. Asimismo, adviértese, dentro del campo mercantil, la exclusión de algún tipo de empresa o de negocios que se consideran poco compatibles con esta forma societaria, por corresponder, ordinariamente, la anónima por razones de organización y del contralor estatal que necesitan las operaciones respectivas.

Traducen lo apuntado, las leyes argentina, paraguaya, uruguaya y chilena $y$, en parte la colombiana, $y$ boliviana y peruana. La primera prescribe en su art. $3 .^{\circ}$ que quedarán sometidas al código y leves de comercio cualquer sea su objeto y que podrán reailzar cualquier classe de operaciones civiles o comerciales, com excepción de bancos, seguro capitalización y ahorro; algunos autores nacionales sostienen que la limitación relativa a negocios bancarios ha desaparecido, pues las leyes que rigen éstos autorizan a efectuarlo hasta a las personas físicas. De igual alcance es la ley paraguaya en el art. $30^{\circ}$ y casi idéntica es la tercera de las indicadas (art. $2^{\circ}$ ), refiriéndose la prohibición a las operaciones bancarias y de capitalización y ahorro en cualquier forma (art. 3. ${ }^{\circ}$, segunda parte). Y la ley de Chile autoriza el establecimiento de la

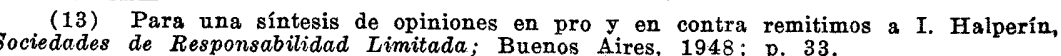

responsabilidad limitada para las sociedades civiles o comerciales (art. $1^{\circ}$ ), con exclusión de los negocios bancarios (art. $2^{\circ}$ ). De la ley de Colombia surge que pueden ser civiles o comerciales a (art. $1^{\circ}$ ), pero sin limitaciones en cuanto al ramo de negocios; y queda dicho que la legislación peruana refiere a sociedades civiles: "Pueden dice el art. 1725 del cód civil - constituirse sociedades civiles de responsabilidad limitada expresándolo así en el acto constitutivo de ellas".

La ley boliviana no menciona las actividades civiles, por lo que debe entenderse circunscripta al campo comercial, y dentro en él prohibe que se dedique a los negocios bancarios en general seguros y cajas de ahorro ( $\operatorname{art} .3^{\circ}$ ). La ley cubana expresa al respecto que "estas sociedades tendrán como objeto cualquiera de lícito comercio..." (art. $1 .^{\circ}$, inc. a) y excluye solamente de la adopción de esta forma a determinados negocios enumerados en el art. 123 del código (sociedades de crédito, bancos de emisión y descuento, compañías de crédito territorial, compañías de minas, bancos agrícolas, empresas concesionarias de ferrocarriles, tranvías y obras públicas y almacenes generales de depósito).

La ley brasileña no se pronuncia expresamente sobre el punto, por lo cual y de acuerdo con lo que surge del art. $10^{\circ}$, debe reputarse a las sociedades por quotas de responsabilidad limitada solamente como mercantiles (13 bis).

Al no determinar nada la ley mexicana hemos de presumir que la forma estudiada se circunscribe al campo mercantil, sin más limitaciones en éste que las actividades que correspondan a las sociedades de responsabilidad limitada de interés público.

6 - Capital. Difícil resulta concretar los muchos aspectos que refieren a este tópico, sobre todo, en forma sintética; por ello, y dadas las exiguas proporciones de nuestro estudio, nos referiremos solamente a las principales cuestiones que tratan las leyes comparadas.

a) Responsabilidad limitada a las aportaciones. Como una característica esencial, ya vista, cada socio responde hasta el límite de lo que aporta a la sociedad. Y así lo refirman las leyes comentadas: la de Colombia, al establecer que la responsabilidad de los socios queda limitada a sus aportes y a la suma que a más de éstos se indique (art. $1^{\circ}$ ) y al exigir una declaración en tal sentido para el registro y publicación (art. $3^{\circ}$ ); la mejicana, que en la primera parte de su disposición, expresa que "sociedad de responsabilidad limitada es la que se constituye entre socios que solamente están obligados al pago de sus aportaciones..." (art. 58), sin perjuicio de las aportaciones

(13 bis) Así lo confirma el tratadista brasileño Noredino O. Alves da Silva, en su 
suplementarias facultativas en proporción a sus respectivos capitales, que contempla el art. 70; y la cubana las considera como "sociedades en las cuales ninguno de los asociados está obligado más allí de su aportación" (art. 1. ${ }^{\circ}$, apartado a). La ley de Bolivia señala en el art. 1. " que este nuevo tipo de compañía es una sociedad" con responsabilidad limitada de los socios" y en el art. 2..$^{\circ}$ expresa además que "en estas sociedades la responsabilidad de los socios queda limitada a la suma de sus aportes o subscripciones en dinero o en otros bienes".

La ley uruguaya contiene la declaración expresa en estos términos: "la responsabilidad de los socios queda limitada en estas sociedades a la cantidad o cantidades estipuladas como aporte de capital en el contrato de constitución de la sociedad" (art. 4..$^{\circ}$. En la ley argentina, fuera de los casos de excepción motivados por constitución irregular o por falta de integración de capital y por el valor atribuído a los bienes (a los que podría añadirse el supuesto que examinaremos luego sobre la falta de aditamentos a la razón social o denominación), la responsabilidad de los socios se limita al valor de la cuota comprometida en el contrato, además en las cuotas suplementarias y de garantía que puedan establecerse $\left({ }^{14}\right)$.

Otras leyes como la brasileña llegan a igual determinación con la exigencia de que se estipule expresamente que la responsabilidad de los socios está limitada al monto total del capital social (art. $2 .^{\circ}$ ): debe aquí destacarse que esta ley no entablece, como otras, que el límite de la responsabilidad de los socios está constituído por sus aportes respectivos, sino por la suma total del capital (14 bis). La ley chilena, además de la enumeraciones generales, impone como contenido del contrato constitutivo, "la declaración de que la responsabilidad

(14) El texto completo del art. 11 dice así:
"Fuera de los casos epecificados en el artic

los socios se limitará: 1.0 Al valor de la cuota colo anterior (a), la responsabilidad de

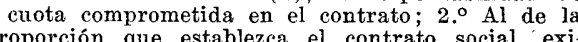
cuotas suplementarias, en da prender necesidedes de su ciro. plementarias no afectan la responsabilidad de los socios ante terceros sino desde el momento en que la sociedad, por resolución inscripta $y$ publicada haya decidido su integración. No cumplidos estos requisitos, ella no es exigible ni aún en el caso de liqui dación o quiebra de la sociedad; $3 .^{\circ}$ Al valor de una cuota suplementaria de garantía,
en la proporción que establezca el contrato solamente exigible en caso de liquidación o quiebra y para responder a obligaciones contraídas con terceros.

También, como se recuerda en el texto, las leyes mexicana (art. 70), chilena (art. una suma suplementaria hasta la cual se extienda la responsabilidad de los socios. Puede aquí señalarse una cláusula de la ley cubana que admite ese pacto de mayor responsabilidad y también el correlativo retiro de la suma complementaria, respetando do constitución de que el capital social pueda aumentarse por entregas sucesivas hecha por los socios, o por la admisión de otros nuevos; e igualmente, sin perjuicio de tercero, su disminución por la retirada total o parcial de las aportaciones efectuadas, mante niéndose el mínimo de capital que fija el apartado letra b)" (art. 1. $0^{\circ}$ inc. o). que subscriben el contrato social, responden solidariamente respecto de terceros por la parte del capital que no se pagare íntegramente en dinero efectivo $\mathbf{y}$ por el valor atribuído 14 bis $)$ Al respecto, y como explicatión, dice Oliveira e Silva: "No tiene - la
ley brasileña - depósito previo de cierta suma de capital, y la responsabilidad del queda limitada a los aportes o a la suma que a más de éstos se indique" (art. 2. ${ }^{\circ}$ ).

b) Suscripción e integración. Por constituir el capital social la única garantía para los terceros, con exclusión de la responsabilidad personal de los socios (salvo siempre supuestos de excepción), es necesario que las legislaciones sean previsoras al respecto, para asegurar una efectiva suscripción o integración, con bienes de existencia debidamente acreditada y con avalúos exactos. A este fin la ley argentina obliga a la suscripción completa del capital y la integración mínima del $50 \%$ - cuyo pago se debe acreditar ante el Registro Público de Comercio con boleta de depósito en Banco oficial o casa de notoria responsabilidad - en el caso de que el aporte sea en dinero (art. 10) Cuando el aporte consista en bienes que no sean dinero, deberá integrarse totalmente en el acto de la constitución (art. 10); para apreciar la cuantía real de los bienes aportados se exige que el instrumento constitutivo contenga en este caso la expresión del valor que se les atribuye y los antecedentes que justifiquen esa estimación (art. 4. ${ }^{\circ}$, inc. $\left.3^{\circ}\right)$. Idéntica a la anterior en su contenido, y casi igual en su redacción, resulta la ley uruguaya (arts. $5^{\circ}$ inc $3^{\circ}$ y $90^{\circ}$ ) lo mismo la ley paraguaya (art. $4 .^{\circ}$, inc. c y $8 .^{\circ}$ ), la cual contiene el agregado de que si entre los aportes figuran inmuebles o buques las escrituras de transferencia deben formalizarse dentro de los ochos días contados desde la inscripción en el Registro Público de Comercio, so pena de responsabilidad solidaria e ilimitada de los socios. También agrupamos aquí a la ley mexicana en punto a que permite diferir el pago de una parte del capital social; dice así en su art. 64: "Al constituirse la sociedad el capital deberá estar íntegramente suscripto y exhibido por lo menos el cincuenta por ciento del valor de cada parte social".

Distinta orientación - en cuanto impone la integración total sigue la ley boliviana: en el art. $7 .^{\circ}$ establece que "estas sociedades

socio, en vez de restringirse al monto de su cuota, abarca la totalidad del capital de la "persona jurídica" (Das sociedas por quotas; 3 . a ed., Rio de Janeiro - 1947, p. 12) ceptos: Todos los socios responden, precipuamente, por la integración de sus respectivas no liberad 8 , subsidiariamente, pero solidariamente, por el pago de las de los otros, todavía responsabilidad limitada, pero en estos términos: el límite sean". La sociedad es de hasta la importancia total del capital social para todos y para cada uno de los nocios. En verdad; es sociedad solidaria, o de nombre colectivo, de responsabilidad limitada" (ab. cit., ps. 155-156).

ocio puede llegar a responder solidariamente por la totaliadade en el texto - también el de falta de integración de una parte del capital que deba abonarse en dinero efectivo y por el valor atribuído a los aportes en especie. Lo que restaría saber es si el prin
cipio de la ley brasileña se aplica solamente al supuesto de falta de interacía do cuotas, especialmente sobreviniendo el estado de falencia (contemplado por el art go las. o si estando ya liberadas totalmente las cuotas, los socios ryodrían - ante una disminución mente hasta ese límite. Literalmente aplicado el principio legal podria conder nueva segunda afirmación, pero la interpretación mós el principio legal podría conducir a la recordadas es la primera; $y$, en tal sentido no habría diferencia substancial con las 
no podrán comenzar su giro, hasta que el total de los aportes esté pagado", supuesto que debe constar expresamente en la escritura de constitución, bajo apercibimiento de responsabilidad solidaria de los socios. Además "los aportes en bienes que no fueren dinero deben ser apreciados al constituirse la sociedad, siendo responsables los socios, solidariamente, en caso de una avaluación falsa notoriamente superior a la real" (art. $8 .^{\circ}$ ).

La ley peruana exige categóricamente como "requisito necesario para la formación de las sociedades de responsabilidad limitada, el aporte total del capital en el momento de constituirse la sociedad" (art. 1726). Dentro de la legislación colombiana se observa respecto a este punto, que la escritura de constitución debe contener en el caso de aportes en especie, la estimación que de ellos hagan los socios (art. $2 .^{\circ}$ ), y que tanto en dicha escritura como en el extracto que debe inscribirse y publicarse, tiene que existir la declaración de que las aportaciones se hallan totalmente cubiertas, lo que excluye el pago parcial de aquéllas (15). Resulta así que estas legislaciones siguen la orientación más rigurosa en materia de aportaciones (16).

Cabe señalar ahora - aunque con referencia también al apartado anterior, ya que se trata de una excepción al principio de la limitación de la responsabilidad - que la lei argentina hace solidariamente responsables, respecto de terceros, a los que suscriben el contrato social, por la parte de capital que no se pagase en dinero efectivo (recuérdese que se admite la integración parcial con un mínimo del $50 \%$ ) y por el valor atribuído a los bienes aportados que no sean dinero (art. 10); muy parecida disposición contiene en igual sentido la ley colombiana (art. $2 .^{\circ}$ ) respecto a los aportes en especie, porque los de dinero se suponen pagados íntegramente; y también la paraguaya (art. $8 .^{\circ}$ ) referida solamente a los bienes que no sean dinero, pese a admitir el pago limitado de ésta, como la argentina (17). de las otras leyes comentadas, mencionamos en el código peruano el

bia, (15) Oonf.: W. Villa Uribe, Las sociedades de responsabilidad limitada en Colombia, 2.a edic. - Bogotá, 1946 - ps. 63-64.

indicado que la doctrina y las leyes dividen sus prefe este estudio dejamos solamente la legislacín francesa, es más conveniente el aporte total, dado que el capital social es la única garantía para terceros; para otros, siguiendo el sistema alemán, puede admitirse necesite para las operaciones sociales. Queda visto que la ley boliviana colombian se peruana, siguen el primer sistema; la mexicana, el segundo con un míninmo del $50 \%$ de integracion; y las de Argentina, Uruguay y Paraguay, un sistema mixto: íntegro chilena, brasileña $\mathrm{y}$ cubana, por lo que ha de estarse a las disposiciones generales que las respectivas legislaciones traen en materia de sociedades; debe añadirse que la segunda de ellas prevé la exclusión del socio remiso en el pago (art. 7) lo que confirma que aplica el principio general de integración a voluntad de los socios, que prescribe
el art. 289 del código mercantil (Conf. Luciano, ob. cit., p. 219, núm. 190; ver además cita de Oliveira e Silva en nota 14 bis)

señala el tratadista de ese paiste en la ley de Paraguay una inexplicable omisión, coma señala el tratadista de ese país. Antonio A. Taboada, en su obra Ouestiones de Derecho. art. 1729, cuyo texto dice así: "No obstante lo establecido (debe entenderse que se refiere al aporte total del capital), los socios son solidariamente responsable entre sí por la totalidad de los aportes que cada uno de ellos se obligó a poner en la sociedad"; no alcanzamos a compreeder bien la concordancia de esta disposición y la recordada que impone la totalidad del aporte, porque si ésta es condición indispensable para la formación no puede quedar obligación pendiente; podríamos entender, por vía de interpretación, que la responsabilidad solidaria funciona en los casos de aportes en especie por avaluaciones exageradas o fraudulentas o por aportes ficticios. $\mathrm{Y}$ en la ley cubana, además de la responsabilidad solidaria igual a las anteriores (art. $1^{\circ}$, inc. c), respecto a las aportaciones en especie, advertimos una adición al código penal (art. $2 .^{\circ}$ de la ley), señalando como casos de estafa la falta de verdad en la escritura de constitución en cuanto a la determinación del capital y la atribución, por medios fraudulentos, a las especies aportadas como capital de un valor superior al real. En la ley brasileña la responsabilidad solidaria de los socios por las cuotas no liberadas funciona especialmente en caso de falencia (art. 9. ): aquí hemos de recordar que la responsabilidad de los socios alcanza al monto total del capital (con el alcance. expresado en nota 14 bis).

Es interesante considerar la cuestión que plantea el aporte de industria. En general no se lo estima como factible en esta clase de sociedades, de acuerdo con un gran sector de la doctrina y jurisprudencia francesas $\left({ }^{18}\right)$; de ello resulta que, aún a falta de disposición que lo prohiba, no es admisible en forma de integración (19) y con mayor razón cuando de la prohibición es expresa como en la ley brasileña (art..$^{\circ}$ que establece que en las sociedades de responsabilidad limitada no habrá socios industriales. Pero, en el cuadro de las legislaciones comentadas, encontramos una disposición de la ley colombiana (art. $4 .^{\circ}$ ), que pareciera admitir lo contrario al establecer

(18) Ver reseña en Halperin, ob. cit., ps. 93-94.

en el campo de la doctrina americana mencionamos a Cervantes tener discordancias, de responsabilidad limitada en el derecho mercantil mexicano - México $1943-$, que afirma que: "La ley no prevé el caso de servicios pero como no lo prohibe, nada impiede que pocio haya ejecutado previamente a la institución o a la sociedad, o que se comprometa a ejecutar después. Entre nosotros, cuando el caso se presenta, se acostumbr que el socio aparezca como aportando en numerario el valor assinnado a su trabajo, $y$ que los mismos fueran valuados" (p. 25). Como se vé, en realidad se acude a un artificio por transformar el aporte de socios en aporte de capital, con lo que se afirm en realidad que aquel es inadmisible, como opina categoricamente el tratadista de la , Rodríguez y Rodríguez (ob. cit., p. 163)

de la legislación patria que permite diferir íntegramente el pago de la cuota (ob. cit ps. $34-36$, núm, 17) 
"que "el aporte de industria no da lugar más que a una participación en los beneficios sociales" $\left({ }^{20}\right)$.

c) Representación y cesión. Com principio básico, según nociones ya anticipadas, el capital no puede materializarse en accionès, sino que integra cuotas sociales de valores determinados o múltiplos de éstos; consecuencia de ello es que no siendo incorporable la parte social a un título de crédito, no resulta transmisible por los medios de negociación de las acciones; las leyes suelen establecer la forma de cesión de las partes sociales, con requisitos que acentúan un rasgo de tipo personal en estas sociedades.

Refirmando lo expuesto se observa en la ley colombiana la disposición del art. 7.: "La acción o interés social no puede ser representado por títulos ni es negociable; pero sí puede cederse", y a continuación se establecen los requisitos necesarios para la cesión incluso el consentimiento de los coasociados. La ley boliviana veda también la representación del capital - que debe fraccionarse en cuotas de cien bolivianos o múltiplos de cien - en títulos negociables (art. $5^{\circ}$ ), y dispone las mayorías necesarias para la cesión de las cuotas a personas ajenas a la sociedade (art. $6^{\circ}$ ).

En la ley argentina aparece preceptuada la división del capital en cuotas de cien pesos o múltiplos de esa cifra y la prohisbición de representarlo por títulos negociables (art. 9. ${ }^{\circ}$ ); en el art. 12 se establecen los requisitos para la transferencia de las cuotas. Las prescripciones que contiene la ley uruguaya refieren a que las cuotas no sean menores de cien pesos (art. $8 .^{\circ}$ ) y a las mismas prohibiciones anteriores; se transmiten por las reglas de la cesión de créditos y con las formalidades allí establecidas (art. 10). Parecidas disposiciones contiene la ley cubana (incs. e y $\mathrm{f}$ del art. $1 .^{\circ}$ ); y la ley paraguaya, en análoga tendencia, establece, además, de la divisibilidade en cuotas de mil o múltiplos de mil, la prohibición de que el capital esté representado por títulos nominativos, endosables o al portador (art. $\left.7 .^{\circ}\right)$ y los requisitos para la cesión (art. 10). La mexicana prohibe el llamado a suscripción pública para la constitución de la sociedad o el aumento de capital (art. 63) (21), y establece la división en partes sociales que pueden ser de valor y categoría desiguales, pero en todo

(20) No hemos de creer que esta disposición resulka clara, pues, no se armoniza
otras de la misma ley que exigen que el aporte se paoue intergamente en el acto de wa constitución, lo que no es posible hacer con el trabajo o industria personal acto do de estas dificultades son las opiniones contradictórias de Villa Uribe (ob. cit., ps. 89.91) quien entiende que "en las socidades. de responsabilidad limitada existe el aporte do anustria; y del socio industrial, como consecuencia, ya que toda persona que hace un
porte garantido por la ley a una sociedad entra a formar parte de ella en calidad de socio", $y$ del distinguido profesor Alberto Zuleta Angel cuya interpretación contraria puede verse en párrafós de sus conferencias transcriptos en la edición del Código do Comercio terrestre de Colombia por José Ortegosa Torres, Bogotá - $1947, \mathrm{p}$, 390.
(21) Esto se justifica no sólo por el núcleo reducido de socios que integran esta
compañia, sino también porque no existe respecto de las mismas una fiscalización estatal gue proteja a terceros suscriptores. caso deben ser de cien pesos o de más de cien (art. 62) y las condiciones para la cesión (art. 65 a 67); además contiene disposiciones relativas a la indivisibilidad de las partes sociales, salvo estipulación en contrario (art. 69) y la unidad de la parte social de cada socio, que acrecerá con nuevos aportes e adquisiciones de las de sus coasociados a no ser que se trate de partes que tengan derechos diversos; resuelve así problemas que otras leyes no contemplan, dando margen a dudas o a discusiones doctrinarias sobre las soluciones que correspondan.

$\mathrm{La}$ ley peruana prohibe la representación por acciones y establece el consentimiento de los coasociados para la cesión (art. 1730). Finalmente, la brasileña, en su título y articulado se refiere a cuotas, excluyendo así a las acciones, y el art. $5^{\circ}$ establece la pluralidad de las cuotas, en el caso de adquisiciones de otras nuevas por parte de los socios ( $\left.{ }^{21} \mathrm{bis}\right)$

d) Monto. Ha sido controvertida la conveniencia de la fijación del límite inferior de la cifra del capital: por una parte se arguye que debe existir una garantía mínima para los acreedores, quienes no cuentan con la responsabilidad personal ilimitada y subsidiaria de los socios; que los gastos de constitución insumirían todo el capital en el caso de que éste fuera muy pequeño; y que se llegaría a crear "organismos fantasmas sin ninguna base seria de responsabilidad y de independencia económica". En sentido contrario se alega que no hay porqué cerrar el acceso a esta forma social a cualquier clase de empresa, por más pequeña que sea; que los socios son los mejores jueces para determinar la cifra necesaria de la inversión; y que el crédito que pueda concederse a esta sociedad dependerá de esa cifra además de los otros factores atendibles -, con lo cual los terceros no sufrirían perjuicio alguno, y podrían graduar sus relaciones con la sociedade según el capital y la confianza que merezca; que toda cifra al respecto es arbitraria, pues varía dentro de un mismo país, de una zona a otra, en el sentido de que lo que resulta capital suficiente en una de reducido movimiento comercial o de pequeña industria, no lo es en las demás, y que oscila en el tiempo, con las fluctuaciones del valor de la moneda $\left({ }^{22}\right)$.

Se pronuncian por un mínimo de cinco mil pesos la ley argentina (art. $9 .^{\circ}$ ), la mexicana (art. 62), la cubana - después de la ley modificatoria del 13 de diciembre de 1929 (según la ley de creación debía ser de veinticinco mil) - y la uruguaya (art. 8. $0^{\circ}$; de cincuenta mil bolivianos la ley de Bolivia (art. 5..$^{\circ}$ ) y de 500.000 pesos la ley para-

(21 bis) Art. 5.०: "Para todos los efectos serán tenidas, corno cuotas distintas, las cuotas primitivas de un socio y las que posteriormente adquiera". Sobre el posible
objetivo o razón de esta cláusula ver Oliveira e Silva ob. cit.. ps. 20-21, núm. 7 . (22) Ver de esta clásula ver Oliveira e silva, ab. 
guya (art. $\left.7 .^{\circ}\right)\left({ }^{23}\right)$. Nada prescriben al respecto las leyes de Brasil, Colombia, Chile y Perú.

Respecto a la fijación de un capital máximo se ha dicho alguna vez, para justificarlo, que debe ponerse un límite porque estas empresas son "la clase media de las sociedades" y que las de grandes capitales deben adoptar la forma de las compañias anónimas $\left({ }^{24}\right)$, Empero, advertimos que, sobre todo en la legislación argentina ello no sería posible en el caso de que los asociados fueran menos de diez, con gran capital; exigirles que adopten la forma de la sociedad anónima, significaria obligarlos a introducir socios ficticios; tenedores nominales pero no verdaderos dueños de las acciones.

La única legislación americana que contiene restricciones a este ú.ltimo respecto es la uruguaya, con el máximo de un millón de pesos.

e) Otras prescripciones. Para afirmar la solidez del patrimonio social, algunas leyes exigem que se detraiga de las ganancias un porcentaje para la formación de un fondo de reserva obligatorio: la argentiná ordena destinar un $5 \%$ de las utilidades líquidas anuales a ese efecto, cesando la obligación cuando el fondo aludido alcance a un $10 \%$ del capital (art. 20); la uruguaya dispone también una reserva del $5 \%$, pero hasta llegar al 50\% del capital (art. 13); para la ley paraguaya es del $2 \mathrm{I} / 2 \%$ hasta llegar al $20 \%$ del capital (art. 19) y para la ley cubana la reserva debe ser del $20 \%$ de las ganancias obtenidas, en cada anualidad, hasta alcanzar el $20 \%$ del capital (art. $1 .^{\circ}$, inc. $\mathrm{m}$ ). Respecto a la ley de Bolivia debe advertirse que dispone la dedución anual del $5 \%$ para el fin indicado, pero sin límite del monto de la reserva legal (art. 10). Las demás leyes no contienen disposiciones al respecto, lo que es criticable $\left({ }^{25}\right)$, porque la exigencia de una reserva legal es una "sabia medida de previsión que redundará en beneficio de los acreedores sociales al conservar en lo posible intacto el capital de la sociedad, su única prenda; sería asimismo útil a ésta puesto que la existencia de reservas para casos imprevistos, sería motivo suficiente para que su crédito se valorice satisfactoriamente" ${ }^{(26)}$. No obstante debe señalarse que en algunos derechos como el mexicano puede llegarse a igual conclusión por aplicación de normas comunes a todas las sociedades (arts. 19, 20 y 22).

(23) Según indica Taboada (ob. cit., p. 206, núm. 202), deba reducirse a guaraníesce según la nueva ley monetaria vigente.
(24), Principio que sustenta de Solá Cañizares, entre otros, en el trabajo citado, "La Ley", Principio que sustenta de Solá Cañizares, entre otros, en el trabajo citado, del capital social, Uribe advierte este vacio y semala que para conjurar la disminución país Colombia - debio exigir el establecimiento de un fondo de reserva obligatorio revaluacín del activo de cada año (ob. cit., ps. 103-104).
(26) Luciano, ob. cit., p. 564, núm. 458 .
Se tutela la integridad del patrimonio de la sociedad con previsiones como las de la ley argentina que dispone que no pueden pagarse dividendos ni hacerse distribución de ningún género a los socios, sino sobre utilidades realizadas y líquidas y que los dividendos pagados en contravención a esa regla pueden ser respetidos hasta cinco años después de su distribuición; además responsabiliza personal y solidariamente a los gerentes por toda distribución hecha sin comprobación previa en las ganancias realizadas o en mayor suma que éstas (art. 21); parecida es la disposición de la ley paraguaya (art. 20). A igual finalidad tiende la ley cubana, pero con un texto más breve, pues dispone que los socios están obligados a reintegrar a la sociedad las cantidades que recibieron en concepto de beneficios que no fuesen realmente obtenidos, responsabilidad que incumbe no sólo a los socios anteriores sino a los cedentes (art..$^{\circ}$, inc. $\mathrm{n}$ ); también la ley boliviana prohibe el pago de dividendos que no provengan de utilidades realizadas, conforme a los balances, y la repetición de los dividendos pagados en contravención a esta regla, contra el gerente que los hubiere abonado (art. 10); en la ley mexicana no existe precepto expreso en lo que atañe a las sociedades estudiadas, pero sí una norma general para todos, en el sentido indicado (art. 19 de la ley citada), y establece que tanto la sociedade como los acreedores pueden repetir los anticipos hechos en contravención a la regla de referencia, contra los que lo hubiesen recibido o los administradores que los hayan pagado, todos los cuales son mancomunada y solidariamente responsables; en la ley brasileña aparece para el caso de falencia, la obligación de los socios de reponer los dividendos y valor recibidos y las cantidades retiradas, a cualquier título, aunque las autorice el contrato, una vez verificado que las mismas fueron distribuídas con perjuicio real del capital realizado (art. 9.0). En las demás legislaciones no hay preceptos expresos sobre el punto ahora glosado, sin perjuicio de que, por vía del derecho supletorio, pueda llegarse a la aplicación de normas que refieran a otras sociedades.

Por último, merece destacarse la disposición de la legislación mexicana que permite que se estipule en el contrato social que los socios tengan derecho a percibir intereses no mayores del nueve por ciento anual sobre sus aportaciones, aún cuando no hubiere beneficios; pero solamente por el período de tiempo necesario para la ejecución de trabajos que seguín el objeto de la sociedad deban preceder al comienzo de sus operaciones, sin que en ningún caso dicho período exceda de tres años; estos ineterses deberán cargarse a gastos generales (art. 85). Queda así resuelta una cuestión, que en ausencia de disposiciones permisivas, provoca controversias sobre su licitud, ya que si la sociedad distribuye intereses que no provienen de utilidades, en realidad disminuye el capital que es la garantía de los terceros; los 
proyectos que precedieron a la sanción de la ley argentina autorizaban la concesión de un interés fijo y un plazo determinado, con beneplácito de una parte de la doctrina, pero ella no prosperó; la Comisión del Senado se expidió así: "La Comisión lo ha borrado deliberadamente. Con él se contrarían los propósitos de garantías a terceros que se persiguen com el resto articulado de la ley, que tiende a la conservación, sin disminución del capital social" ${ }^{27}{ }^{27}$.

7 - Razón social o denominación. Pese a algunas críticas que se han hecho, resulta general la facultad de que las sociedades de responsabilidad limitada utilicen, una razón social; y algunas leyes establecen que puede usarse también una denominación. Se trata, en términos generales, de entes de tipo mixto, en lo que respecta al carácter de sociedades de personas o de capital, y por ello suele existir esa doble posibilidad.

De las leyes aquí revistadas, la argentina establece que pueden tener razón social o denominarse por su objeto o por el nombre que los socios le atribuyan (art. $2 .^{\circ}$ ); también la ley mexicana admite la alternativa del uso de una razón social, que se formará con el nombre de uno o más socios, o de una denominación (art. 59) y la Colombiana faculta para adoptar una razón social o la designación del objeto de la compañía (art. $8^{\circ}$ ); la brasileña también refiere a esa opción, pues establece (art. $3^{\circ}$ ) que esas sociedades adoptarían una firma o denominación particular, y agrega que cuando la firma no. individualice a todos los socios, deberá contener el nombre o firma de uno de ellos, debiendo la denominación, en cuanto sea posible, dar a conocer el objeto de la sociedade ( ${ }^{27}$ bis); y la ley uruguaya dice textualmente así en lo pertinente (art. $3 .^{\circ}$ ): "Las sociedades limitadas deberán tener una razón social y denominarse por su objeto, o adoptar un nombre cualquiera...", con lo que pareciera exigir que concurran la razón social y la individualización por su objeto. Permiten solamente el uso de la razón social las leyes boliviana (en cuyo art. 4. ${ }^{\text {. }}$ se menciona sólo a la firma social, aunque por la remisión al art. 231 inc. $2 .^{\circ}$ del código mercantil, podría resultar el uso de la denominación), cubana (art. $1 .^{\circ}$, incs. a y d), y la chilena (art. $4 .^{\circ}$, donde se habla ùnicamente de firma o razón social); la ley peruana debe considerarse definida en el mismo sentido porque contiene una cláusula en la cual permite que cuando el apellido de todos los socios sea el mismo, bastaría su incorporación (art. 1727), lo que refiere sin duda la razón social, y lo refirma la circunstancia de que la reglamentación

(27) Diario de Sesiones, Cámara de Senadores, año 1932, t. I, p. 835. Además, es la inmutabilidade del capital social, en el sentido de la merma, $\mathbf{y}$ con éste artículo mente esa característica (p. 836). (27 bis) Puede consultarse al respecto la obra de Heitor Beltrão. Sociedades de

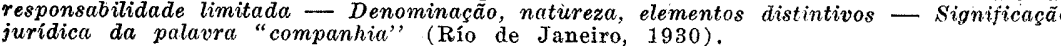

se encuentra en el título general de las sociedades donde se exige la expresión de la razón social en la escritura constitutiva (art. 1689). En último lugar, señalamos que la ley paraguaya prescribe literalmente (art. $2 .^{\circ}$ ) que: "Dichas sociedades deben tener una denominación. (formada con el nombre de uno o más socios seguido o no de la adición "y compañía", por el objeto de la sociedade o un nombre de fantasía)...."; nos parece que aunque se hable de denominación, bajo este término se engloba tanto el uso de la razón social como el de la denominación propiamente dicha.

Todas las leyes, sin excepción, contienen exigencias para identificar a una sociedad de este tipo y evitar su confusión con otras, especialmente con las coletivas, en el supuesto de que se adopte una razón social. En esta orden de cosas, la ley argentina requiiere que la firma o denominación estén precedidas o seguidas de las palabras "sociedad de responsabilidad limitada" y la enunciación del capital social (art. $2 .^{\circ}$ ); aunque aquí no se advierte apercibimiento expreso, debe entenderse que la omisión puede tener como pena la caducidad del beneficio de la limitación de la responsabilidad en el caso de que con la omisión se llama a engaño y prejudicial a un tercero, salvo - como opina la mejor doctrina - que el acto celebrado revelara al tercero la natureleza de la sociedad. El art. $7 .^{\circ}$ obliga a las mismas enunciaciones en todos los documentos, facturas, anuncios y publicaciones emanadas de la sociedad; aquí la infracción está expresamente penada con multa de 50 a $900 \$ \mathrm{~m} / \mathrm{n}$. en beneficio del Consejo de Educación de la jurisdicción respectiva.

Impone la ley de Cuba el uso de las palabras "sociedad limitada" después de la razón social (art. $1^{\circ}$, inc. a), y debe, además, incluirse el vocablo "compañía" antepuesto a los anteriores si en la razón social no figura el nombre de todos los socios; y en todos los actos, facturas, anuncios, publicaciones o cualquier documento que proceda de la sociedad, deberá consignarse, antes o inmediatamente después. de la razón social, el montante del capital social (art. $1 .^{\circ}$ inc. d); como en el caso de la ley argentina, la infracción a este último precepto se pena con multa (de trescientos e quinientos pesos, imponible por la Secretaría de Agricultura, Comercio y Trabajo, según el texto primitivo y hoy por la Secretaría de Comercio). La ley boliviana tiene a este respecto también dos disposiciones: la del art. $4 .^{\circ}$ que exige que la firma social termine con la palabra "limitada", "sin la cual los socios serán solidariamente responsables de las obligaciones sociales"; y la del art. 12 que prescribe que "en todos los documentos, facturas, anuncios y publicaciones de estas sociedades, se indicará la calidad de "limitada", pena de responder en caso de omisión, de las obligaciones sociales como socios colectivos". De parecido modo, la ley paraguaya establece que la denominación social debe estar prece- 
dida o seguida del aditamento "sociedad de responsabilidad limitada", íntegramente escrito, y que ambas - designación y aditamento más la enunciación del capital inicial se insertarán en todos los documentos, anuncios y publicaciones sociales, so pena de multa de $\$ 20.000 \mathrm{~m} / \mathrm{n}$. por cada vez, aplicable por el Ministerio de Hacienda (art. $2 .^{\circ}$ ).

En la ley peruana de dispone el uso de las palabras "sociedad de responsabilidad limitada" (art. 1727) y, además, que en todos los rótulos y avisos de publicidad deba estar la indicación de ser limitada la responsabilidad y el monto del capital, bajo pena de perder los socios el beneficio de la limitación (art. 1728). Para la uruguaya es obligatorio solamente el uso de la palabra limitada, después de la razón o denominación social, sin especificarse sanción, por lo que entendemos, que rigen principios generales (responsabilidad solidaria o ilimitada en el caso de que la omisión cause un perjuicio que así lo imponga); las leyes colombiana y chilena, prescriben el mismo agregado, con la sanción de que, en caso contrario, los socios cuyos nombres figuren en la razón social son solidariamente $\left({ }^{28}\right)$ responsables de las obligaciones sociales (art. $8 .^{\circ}$ y respectivamente); la mexicana se refiere al uso de las palabras "sociedad de responsabilidad limitada" después de la razón o denominación social, so pena de sujetar a los socios (debe entenderse que a todos, no como en las anteriores, que se refieren solamente a los incluídos en la razón social) a la responsabilidad de las sociedades colectivas (arts. 59 y 25) ( ${ }^{29}$ ) Finalmente, la ley brasileña obliga a poner la palabra limitada después de la firma o denominación social; caso contrario serían solidaria

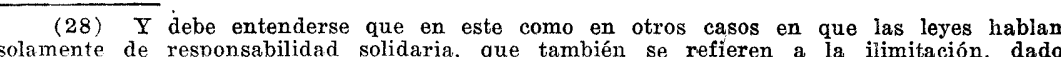
solamente de responsabilidad solidaria, que también se refieren a la ilimitación, dado típico $y$ característico de las sociedades que nos ocupan. Corrobora este aserto la opinión de Villa Uribe al expresar que dicha cláusula de la ley colombiana "es de gran trancendencia por que sirve para diferenciarla sustancialmente de cualquier otra
pañia, y sin ella se convierte de hecho en sociedad colectiva" (ob. cit., p. 40). Jure condendo. nos parece importante diferenciar dos situaciones: aquéllas en que la omisión se comete en un anuncio, factura, etc., sin perjuicio para terceros; como la pérdida del beneficio de la limitación. En cambio cuando sería sancín excesiva contrato, por ejemplo, y perjudica a terceros, puede llegarse a la pérdida del beneficio aludido, si éllos son llamados a engaño sobre el carácter de la sociedad con que tratan, resultan perjudicados. Las leyes comentadas no llegan a esta diferenciación, salvo al del art. 7 . El art. 7 se refiere a la inscripción en papeles, facturas, avisos, etc. es decir, a la publicidad permanente; en cambio el art. 2 se refiere al empileo en los actos $y$ contratos que subscribe la cociedad. Es evidente que en los supuestos del art. 7 no contrato que se suscribe sin esa aclaración. En este caso deben ampararse a terceroo y si la sociedad actúa con una apariencia de sociedad colectiva, induciendo en erro (29) Precisamente este reenvío confirma lo expuesto en la primera parte de la nota anterior, ya que es de la esencia de las sociedades colectivas primera ysí lo reitera el mencionado art. 25 - que los socios responden ilimitada y solidariamente por las
obligaciones sociales. e ilimitadamente responsables los socios gerentes y los que hicierem uso de la firma (art. $3 .^{\circ}$ ).

Respecto a la posibilidad de utilizar una abreviatura de las palabras impuestas como agregados de la razón o denominación social, la única expresa es la ley mejicana, que permite el empleo de la sigla S. de R. L. (art. 59). Las demás - salvo la ley paraguaya, que, como hemos visto, impone expresamente la escritura íntegra - dejan en pie el problema que plantea al respecto la doctrina; muchos autores opinan que, a falta de autorización expresa de la ley, deben usare las palabras íntegras. Por nuestra parte, pensamos que sólo es menester que destaquen su característica peculiar y que, para ello bastan abreviaturas que lo indiquen claramente; tenemos en cuenta para decidirnos por esta opinión que la abreviatura - en definición del Diccionario de la lengua española de la Real Academia - es la "representación de las palabras en la escritura con sólo varias o una de sus letras", y en ese sentido "S. de R. L." o "Soc. de Resp. Ltda." o "Ltda." (en las leyes que sólo requieren ese vocablo) son suficientemente conocidas y se han impuesto en el uso de tal manera que nadie puede dudar de la clase de sociedad a que están destinadas a identificar $\left({ }^{30}\right)$; otra razón, además, para admitirlas — aún a falta de disposición que lo permita - es la de que el comercio exige fórmulas fáciles y simplificadas, y esto contribuye, en su medida, a esa facilitación.

Otros aspectos que podría tratarse respecto a la razón social en estas sociedades, entran en la órbita de consideraciones generales en la materia por lo que nos abstenemos a hacerlo. Solamente, para cerrar el capítulo, indicamos la existencia de una disposición en la ley mexicana (art. 60) que establece que "cualquier persona extraña a la sociedade que haga figurar o permita que figure su nombre en la razón social responderá de las operaciones sociales hasta por el monto de la mayor aportación".

8 - Gobierno, administración y fiscalización de la sociedad

a) Colectividad de los socios. - Como señala Feine, a los socios en conjunto compete en suprema instancia la formación interna de la voluntad colectiva, y por tanto, la dirección fundamental de la sociedad. En sus acuerdos toma cuerpo la voluntad directiva de la corporación. "Constituyen, por consiguiente, en cuanto colectividad, el órgano supremo de la sociedad Ltda." ( ${ }^{31}$ ).

En lo que respecta a los casos en los cuales se requiere la decision del cuerpo de socios y la forma de manifestarse la voluntad de éstos, las leyes estudiadas son dispares. Algunas carecen en absoluto

(30) Nos referimos especialmente a la República Argentina, donde raramente so (31) E. Fieine, ob. cit., p. 235.

18 - R. D. $10^{\circ}$ Vol. 
de normas, como la chilena - de texto muy escueto, en general y la. peruana, por lo que debe entenderse que imperan las normas generales. peruana, por lo que des. Otras continuen muy pocas previsiones, que dando la fijación de normas para el contrato social, que puede estadando consulta por escrito a los socios, soluciones que se escogerán, va de suyo, de acuerdo con el número de éstos. Y algunas son más detallistas al respecto.

Entre las del segundo grupo se cuenta la ley colombiana que sólo requiere el pronunciamiento de los socios para el caso de cesión de cuotas (art. $7 .^{\circ}$ ); también la ley argentina cuyas únicas referencias son las de la decisión del cuerpo social para la obrigatoriedad de aporte suplementario (art. 11, inc. $2 .^{\circ}$ ), para la cesión de cuotas (art. 12), y la exerción de responsabilidad a los gerentes (art. 15), y en este último caso habla expresamente de asamblea; para lo demás. "el contrato social determinará la forma y manera como se expresará la voluntad de los socios para la aprobación de los balances, nombramiento y remoción de los gerentes y demás resoluciones que interesen a la sociedad" (art. 17); y establece, además, las mayorías requeridas para las modificaciones del acto constitutivo (art. 18) y la forma de computarse los votos (art. 19). No impone así, ni reglamenta las asambleas, por lo que puede acudirse y se lo hace a menudo - al régimen de la consulta o de resoluciones por escrito sin las formalidades de aquellas reuniones. En iguales términos situamos a la ley paraguaya, que remite - como la precedente - a lo que disponga el contrato social (art. 16).

La ley brasileña poco dice sobre el particular, ya que solamente habla de resoluciones sociales para algunos aspectos: exclusión de socios remisos, adquisición, por la sociedad de sus cuotas y, en general, de las deliberaciones de los socios, sin expresar cómo se deben adoptar (arts. 7, 8 y 16).

De mayor amplitud - y ya ubicable en el tercer grupo - resulta la ley uruguaya, pues impone como enunciación obligatoria del instrumento fundamental la forma de reunirse y facultades en las asambleas sociales y del ejercicio del derecho de voto por los socios (art. 5. $._{\text {inc }} .^{\circ}$ ); establece para la cesión de cuotas y para resolver la disolución de la sociedad la necesaria concurrencia de una mayoría de personas y capitales (arts. 10 y 15 , inc. $2^{\circ}$ ); dispone la realización de una asamblea social cada año, por lo menos, para la aprobación del balance y examen de la gestión de los administradores (art. 12); y finalmente, exige como indispensable un libro de asambleas (art. 16).

También la ley cubana resulta de las definidas a ese respecto, porque resuelve que los acuerdos se tomarán en sesión - así denomina a la reunión de socios - que celebren los mismos, cuando el número de ellos excediera de cinco, y por la mayoría de votos que representan más de la mitad del capital social; queda pues la libertad de reglamentación estatutaria, cuando el número de socios fuere menor del indicado. También establece las mayorías para segunda convocatoria y las formas de las citaciones para las juntas; deja librado a los estatutos la fijación de la época en que se efectuarán las sesiones ordinarias y extraordinarias, debiendo realizar-se por lo menos una vez al año (art. $1 .^{\circ}$, inc. i), y fija materia para acuerdos y sus mayorías correspondientes en la cesión de cuotas (art. $1^{\circ}$, inc. f), cambio de nacionalidad (inc. k) y modificaciones del contrato social (inc. l).

En la ley boliviana figura esta disposición que transcribimos literalmente: "Las decisiones de la sociedad se tomarán en asamblea por mayoría que represente el cincuenta por ciento del capital social. Podrán también ser solicitadas por escrito, emitiéndose los votos en la misma forma, sin necesidad de reunión en asambleas. En todo caso, habrá una asamblea general una vez por año cuando menos. Cada socio tendrá tantos votos como cuotas haya suscripto y pagado, pero en ningún caso un socio podrá representar más del treinta y cinco por ciento del capital social" (art. 13). Resulta, pues, obligatoria una asamblea anual, por lo menos, cuya competencia no se especifica en la ley, pero debe entenderse que, en primer término y en forma regular, debe ser lo atinente a la probación del balance y fijación de dividendos. Respecto al voto figura la interessante disposición de limitar al máximo que corresponda a un socio, para evitar que quede en sus manos el gobierno de la sociedad, cuyo carácter - según hemo señalado varias veces - se ha considerado, en líneas generales, como mixto: intuitue personae e intuitue pecuniae. Existen además disposiciones que fijan la mayoría para la cesión de cuotas (art $6^{\circ}$ ), nombramiento de gerente extraño a la sociedad (unanimidad, según el art. $9 .^{\circ}$ ), y cambio de objeto, aumento o disminución del capital o fijación de mayor responsabilidad de los socios, también por acuerdo unánime (art. 16).

La de mayor amplitud en punto a normas relativas al gobierno de la sociedad, nos resulta la ley mexicana: en su disposición básica al respecto (art. 77), establece que "La asamblea de los socios es el órgano supremo de la sociedad"; fija las mayorías para primera y segunda convocatorias, además de lo prescripto en el art. 76 sobre acción de responsabilidad contra los gerentes y en el art. 83 sobre modificaciones del contrato social (art. 77); determina las facultades de las asambleas (art. 78 en XII apartados), reconoce el derecho de los socios a participar en las mismas (art. 79), obliga a una reunión mínima anual (artículo 80) y reglamenta la forma de convocatoria (art. 81). Y también dispone que el contrato puede consignar los casos en que la reunión de la asamblea no sea necesaria y, como 
consecuencia sea posible suplirla con el voto por escrito; pero queda a los socios que representan más de la tercera parte del capital social el derecho de exigir, pese a la disposición estatutaria, la runión de la asamblea (art. 82).

b) Administradores. Resulta frecuente la disposición de encomendar la administración de estas sociedades a uno o varios gerentes, socios o no. Así las leyes argentina (art. 13), boliviana (art $9 .^{\circ}$ ), paraguaya (art. 12), mexicana (art. 74), y cubana (art. $1 .^{\circ}$, inc. g), con la salvedad de que esta última especifica que las sociedades referidas "estarán gobernadas y administradas por un uno o más mandatario". Aparece determinada de esta manera, en forma expresa, la posibilidad de que se excluya a los socios de la administración social, en virtud de las razones que en cada caso aconsejen la intervención de un extraño, si bien estos han de actuar con el debido control de los socios; el carácter de socio no confiere per se el derecho a la administración, si no media la designación como gerente. Una cuestión que se plantea para las legislaciones aquí agrupadas, es la emergente del supuesto en que el contrato sea omiso respecto a la designación de administradores: \& debe considerarse en tal caso que la administración corresponde a todos los socios, o no?; la ley mexicana la resuelve expresamente en el primer sentido al remitir en el art. 74 a la disposición del art. 40 que así lo prevé respecto a las sociedades colectivas; en las demás subsiste la duda $\left({ }^{32}\right)$.

Aparte'de las leyes mencionadas, la uruguaya se refiere solamente a la designación de administradores, que deberá hacerse en el contrato ( $\operatorname{art} .5 .^{\circ}$, inc. $4 .^{\circ}$ ); por lo que no está en el mismo plano que aquéllas, máxime cuando, por tener como derecho supletorio las disposiciones relativas a sociedades colectivas (art. 18), hay que acudir a los principios vigentes para éstas. La ley colombiana establece que"... la adminsitración corresponde de edrecho a todo y cada uno de los socios, los que pudren desempeñarla por sí misma o por sus delegados, sean socios o extraños" (art. $1^{\circ}$ ), consagra de este modo, un principio distinto al ya comentado; el carácter de administrador es un derecho del socio, y no necesita estar conferido mediante nombramiento expreso ${ }^{\left({ }^{3}\right)}$. La ley brasileña resuelve que "el uso de la (32) Constreñidos por los límites del trabajo, sólo podemos llamar la atención
sobre el problema y hacer unas breves referencias. Creemos que las legislaciones arriba citadas - excepto la de México - no mantienen el principio de las sociedades coletivas, en las cuales los socios son administradores natos, y, por tanto, en defecto de designacarácter (como lo disponen expresamente los arts. 291, inc. $30^{\circ}$ y 411 del cód. de comercio argentino); aquí se ha creado un sistema especial de administración, con la institución del gerente, y así se dijo en el debate parlamentario que precedió a la sanción lo cual una persona ejerce la representación de la sociedad...": "De todas maneras es indispensable que haya una persona que represente oficialmente a la sociedad y cuya designación este inscripta en el Registro Público de Comercio" (ver Halperín, ob. cit., ps. $135-137$ ). firma social corresponde a los socios gerentes; si, no obstante, el contrato social fuese omiso, todos los socios la pueden usar" (art. 13); desígnase aquí al administrador con el nombre de gerente, pero no con las mismas características que en los estatutos legales mencionados en el párrafo anterior, ya que se correlaciona con la calidad de socio. La ley chilena calla sobre el particular, por lo que usando del derecho supletorio que reconoce ( $\operatorname{art} 4^{\circ}$ ) se aplica el principio del mandato recíproco para administrar, en defecto de designación (art. 386 del cód. de comercio chileno). Y la peruana nada dispone en especial, ya que es completa la remisión a lo que en el mismo código se legisla para todas las sociedades, sin ningún matíz diferencial que nos interese destacar.

Sobre el nombramiento y remoción de los gerentes, mandatarios o administradores, no entraremos en mayores detalles que los siguientes, tomados de las leyes que preven especialmente estos aspectos: la argentina dispone que podrán nombrarse en el contrato social o en documento posterior, el cual sólo tendrá validez y efecto después de la inscripción y publicación (art. 13); según la ley boliviana el gestor o gestores (gerentes) serán designados por libre elección de los socios, pudiendo ser separados a instancias de los mismos, siendo indispensable el acuerdo unánime de los socios para que pueda ser designado gerente un extraño (art. 9. $)$; la de México establece que los gerentes podrán ser designados temporalmente o por tiempo indeterminado y que, salvo pacto en contrario, la sociedad tendrá derecho para revocar en cualquier tiempo a sus administradores (art. 74), siendo todo ello facultad de la assamblea (art. 78, apartado III); para la ley cubana, los mandatarios gerentes deben ser nombrados en el acto de constitución o posteriormente, por tiempo limitado o ilimitado y podrán ser removidos por causa legítima y comprobada (art. $1 .^{\circ}$, inc. g); se encuentra en la ley paraguaya el art. 12 que establece que los gerentes serán nombrados en el contrato social, por tiempo limitado o ilimitado y que esta designación podrá ser revocada, con causa o sin ella por la mayoría prevista en el art. 18 , segunda parte $\left({ }^{34}\right)$, y para que la revocación y nuevo nombramiento surtan efecto frente a terceros se requiere la inscripción y publicación de estos actos; y en la ley uruguaya solamente encontramos que el administrador o administradores serán nombrados en el contrato (art. $5 .^{\circ}$, inc. $4 .^{\circ}$ y 11 ). En las leyes brasileña y peruana no se dispone nada al respecto, por lo que, por

(33) Corrobora esta conclusión la remisión que Villa Uribe (ob. cit., p. 88), hace expresa, se entiende que todos los socios se confieren recíprocamente el mandato para administrar, o sea que la cosiedad no tiene obligación de nombrar administrador o gerente. p. (34) Debe querer referirse al art. 15 segunda parte (conf. Taboada, ob. cit., p. 210), o sea la votación fnvorable de socios por representantes de las tres cuartas 
aplicación de normas generales o de reenvío, deben aplicar-se lo correspondiente a otras classes de sociedades ${ }^{35}$ ).

$\mathrm{Y}$ en lo tocante a poderes, existe la disposición de la ley argentina que obvia dificultades respecto al alcance de los mismos, al disponer que "los gerentes tendrán todas las facultades necessarias para obrar a nombre de la sociedad, salvo disposición contraria de sus estatutos" (art. 13), en lo que siegue la ley paraguaya (art. 14); de parecido alcance resulta la ley cubana:" ...tendrán la plenitud de facultades en frente de terceros, obrando indistintamente como en asunto propio, salvo las limitaçiones expresamente consignadas en los estatutos" (art. $1 .^{\circ}$ inc. g). Para la ley boliviana, en cambio, debe estarse a las facultades que se otorguen expresamente a los gerentes (art. 9. ${ }^{\circ}$ ), lo que supone uma especial previsión en los contratos constitutivos para evitar omisiones. Las demás no son explícitas sobre el particular ${ }^{(36)}$, afirmación que cabe también en el caso de la ley brasileña - aunque ésta fije algunos casos de responsabilidad social por los actos del gerente (arts. 13 y 14) ya que carece de una norma general.

(35) Referente a la legislación brasileña, Luciano entiende que la forma de

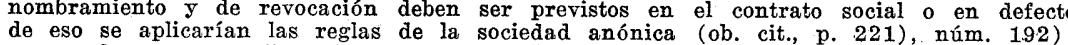
coneuerda con esta afirmación Oliveira e Silva al decir - en el caso de revocación que: "Mandando el decreto n..$^{\circ} 3708$, de 1919, observar, en cuanto a las sociedades po cuotas, en silencio del respectivo estatuto, $\mathrm{y}$ en parte aplicable, las disposiciones de
la ley de sociedades anónimas, podrá el gerente de aquellas sociedades ser destituido, por los demás socios, en cualquer tiempo.." (ob. cit., p. 32, núm. 15). Debe recor darse que Ferreira no supone a las reglas sobre sociedades anónimas aplicables como respecto a la ley colombiana, Villa Uribe entiende que "Los administradores pueden ser nombrados en el acto de constitución, por medio de los estatutos, o en un momento cualquiera de la vida de a sociedad, siendo nombrados por los socios. Pero si el nom hacer posterermente herocación de dicho pombramento", se entiende que los socios se confieren recíprocamente la facultad de administrar( ob.

(36) Por ello se necesita acudir a aplicaciones de principios generales, a interpretaciones analogicas o a remisiones. Para el caso de la ley colombiana, Villa Uribe
entiende que: "Si al hacer el nombramiento de administrador o administradores los socios hubieran determinado la extensión de los poderes que confieren a éste, el nombrado tiene el caracter de un simp e mandatario y sus facultades están reducidas a lo ctos $y$ contratos comprendidos en el giro ordinario de la "sociedad, o que sean condu centes al logro de los fines que ella se hubiera propuesto" (ob. cit., p. 90). "También
existe una referencia al carácter de mandatarios de los gerentes, en la ley uruguaya

(art. 11).
Para el caso del derecho mexicano, y como lo indica expresamente Rodríguez $y$ Rodriguez (ob. cit.; p. 168), las atribuciones son amplisimas, de acuerdo con la dis-
posición básica del art. 10 de la ley sobre sociedades mercantiles; "La representación de toda sociedad correspondería a su administrador o administradores, quienes podrán realizar todas las operaciones inherentes al objeto de la sociedad salvo lo que expresamente firmación de Luciano en el sentido de que las atribuciones del gerente deben ser previstas en el contrato social o aplicarse "subsidiariamente las disposiciones de la ley sobre las sociedades anónimas, ya que ninguna previsión se contiene al respecto en En general, puede decirse que en todos estos casos de silencio, debamos tener como órbita de atribuciones de los gerentes o administradores las que marque el contrato social, o en su defecto las de los administradores del tipo de figura jurídica a que se pueda remitir en cada caso
en materia de sociedades.
Como último aspecto de este apartado, hemos de decir que también la mayoría de las leyes establecen las prohibiciones que enmarcan la acción de los administradores y sus responsabilidades. "Los gerentes no podrán realizar operaciones por cuenta propria de las que sean objeto de la sociedad ni asumir la representación de outra persona o sociedad, so pena de pérdida del empleo y daños y perjuícios". "Los gerentes responden respecto de la sociedad, personal y solidariamente, según sean los términos del mandato, por mal desempeño del mismo y por violación de la ley o de los estatutos. La acción de responsabilidad e interés de la sociedad, por esta causa o sobre reintegração del capital social, corresponde a la sociedade o a los socios individualmente; pero éstos no podrán ejercerla, si la asamblea por voto favoráble de las tres cuartas del capital, declara exentos de responsabilidad a los gerentes. Los acreedores sociales sólo podrán ejercer la acción de responsabilidad, por reintegración del capital, en los casos de quiebras o liquidación de la sociedad" (ley argentina, arts. 14 y 15). La misma prohibición contiene la ley paraguaya (art. 13), la cual tambén, en punto de responsabilidad, acepta los dos primeros párrafos transcriptos de la ley argentina art. 15 de la ley paraguaya).

La ley de México establece sobre el punto que "La acción de responsabilidad en interés de la sociedad, para el reintegro del patrimonio social, pertenece a la asamblea y a los socios individualmente considerados; pero éstos no podrán ejercitarla cuando la asamblea, con un voto favorable de las tres cuartas partes del capital social, haya absuelto a los gerentes de su responsabilidad. $\mathrm{La}$ acción de responsabilidad contra los administradores pertenece también a los acreedores sociales; pero sólo podrá ejercitarse por el síndico, después de la declaración de quiebra de la sociedad" (art. 76). Para la ley cubana "Los gerentes son responsables individual o solidariamente, según los casos, para con la sociedad y terceros, de las infracciones legales, violación de los estatutos y faltas que cometieran en sus gestiones" (art. 1. ${ }^{\circ}$, inc. g). En la ley uruguaya se hace personalmente responsables al administrador o administradores del cumplimiento de todos los preceptos contenidos en la misma y se les asignan las prohibiciones legales establecidas para los mandatarios (art. 11). La ley brasileña establece que los socios gerentes responden para con la sociedad y los terceros, solidaria e ilimitadamente, por exceso en el mandato o por los actos practicados con violación del contrato o de la ley (art. 10).

Para la ley boliviana "Los socios gerentes y administradores no podrán dedicarse por su cuenta a las mismas actividades que, según el contrato debe desenvolver la sociedad" (art. 9.9); no contiene cláusula especial sobre responsabilidad. Las restentes leyes - 
colombiana, chilena, y peruana - nada expreso disponen sobre et particular.

c) Fiscalización. - En este aspecto se advierten dos tendencias en las leyes comentadas: una la de las que nada expresan de lo concerniente al control conjunto de los socios, como las argentina, uruguaya, brasileña, paraguaya, colombiana, chilena y peruana, respecto de las cuales debe estarse, en unos casos a los que se establezca sobre eso en el contrato social, y en otras a normas de aplicación general o supletoria si cupieren. Destacamos que nos referimos al control permanente y conjunto de los socios - por medio de sindicaturas o asociaciones o consejos de vigilancia - porque el individual de aquéllos, en cuanto a la información sobre la marcha de los negocios, examen de libros y papeles de la sociedad, verificación de las existencias, etc., emana de normas comunes a todas las sociedades (caso de la ley argentina, art. 284 del cód. de comercio), de disposición, expresa de la ley específica (como lo dispuesto por el art. 18 de la de Paraguay), o de soluciones propugnadas doctrinariamente. Además debe advertirse que en la ley uruguaya está prescripta la fiscalización de la inspección de Bancos y Sociedades Anónimas no sólo para la verificación de la realidad de aporte de capital, sino en forma más general, ya que "podrá en todo caso de denuncia de irregularidad, ejercer inspección en esta clase de sociedades y solicitar al Juzado de comércio las medidas que sea pertinentes" (art. 19).

Las de la segunda orientación, legislan expresamente sobre el particular. De este modo la ley boliviana prevé que cuando el número de socios pase de diez, podrá constituirse un directorio o consejo de super vigilancia, cuyos miembros serán personalmente responsables ante los socios o ante terceros de las faltas que hubieren cometido en su perjuicio (art. 14); y la misma disposición establece la facultad individual antes aludida. La ley mexicana dice literalmente en su art. 84: "Si el contrato social así lo establece, se procederá a la constitución de un Consejo de Vigilancia, formado por socios o personas extrañas a la sociedad, correspondiendo la designación de este Consejo a la asamblea" (art. 78 apartado IV) además, se alude expresamente a este organismo de darle la facultad de concovocar a las asambleas cuando no lo hicieram los gerentes (art. 81). Y la ley cubana, la más prolija sobre el punto, establece en forma imperativa - no potestativa, como las anteriores - que en las sociedades cuyos miembros excedieren de cinco, habrá una comisión fiscalizadora que velará por el buen cumplimiento de los administradores, nombrada en los mismos estatutos y compuesta del múmero de personas que se designaren, no excediendo de três; añade que esta comisión no responderá, en manera alguna, de los actos de los gerentes, ni de sus resultados; pero sí responderá para con la sociedad y los terceros de las faltas personales en la ejecución del manda to art. $1 .^{\circ}$, inc. 11 ).

Como juicio valorativo sobre este aspecto hemos de expressar que el silencio de las leyes no se justifica porque además de que los contratos sociales pueden ser imprevisores, los terceros están interesados en el establecimiento de un adecuado control de la marcha de la sociedad - como se lo ha destacado - por la limitación de la responsabilidad de los socios. Normas flexibles, que distingan los casos de sociedades de pocos integrantes y las de un número apreciable de ellos, son preferibes al silencio de la ley.

8. - Disolución. Ya aludimos incidentalmente a la questión relativa a la índole de esta sociedad, en el sentido de si son de las. llamadas de personas o de capitales. No podemos aquí (los límites: del trabajo nos lo vedan) dilucidar el punto, sino solamente señalar que, según se apoyen en uno $u$ otro aspecto, hay argumentos para ambas tesis. Ahora aparecerían en favor de la segunda, ya que, por lo general las leyes descartan como causales de disolución algunas que lo serían para las sociedades colectivas y que refieren a eventualidades acaecidas respecto de los socios: muerte, interdicción 0 quiebra de los mismos.

Tampoco podemos llegar a la correlación de los preceptos especiales con el sistema géneral de las leyes de cada país, para establecer qué causales de orden general se aplican, por lo que nos limitamos a transcribir al pie las disposiciones especiales que existen $\left({ }^{37}\right)$.

9. - Derecho supletorio. Uno de los tópicos más espinosos es éste. Si las leyes no son previsoras, surge la cuestión de las normas aplicables en subsidio: si las de las sociedades colectivas por considerarse a las de responsabilidad limitada como de tipo personal,

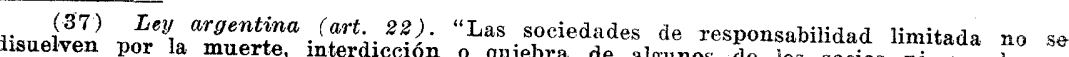
disuelven por la muerte, interdicción o quiebra de algunos de los socios ni por no la re.
moción del gerente socio nombrado en el contrato salvo disposición contraria de los.
estatutos. La quiebra de la sociedad no importa la de los Ley boliviana (art. 11). "Estas sociedades no se disuelven por la muerte, inte"." incapacidad o quiebra de alguno o algunos de sus socios, salvo pacto en contrario. capital o por otras demandar la disolución de la sociedad por pérdida de la mitad de euyas participaciones sociales representan juntas a sociedad, los socios Igualmente los socios pueden acordar, por mayoría de votos, la disoliación de la lo menos. verán por da remación del gerente o gerentes, socios de la uno mas de sus socios, ni por la disposición contractual en contrario. La quiebra de la sociedad no importará la de los socios que la compongan En la ley colombiana (art. 5.०) puede recordarse como causa peculiar de disolución
la de que el número de socios aumentare a más de veinte.

altín se contempla en un capitulo único todo lo referente a disolución de sociedades - que establece que "La pacidad, exclusión o retiro de uno de los socios, o porque el contrato la muerte, inca. respecto a uno de ellos" (art. 230 ), a contririo sensu, se infiere claramente que ello no
ocurre en las de responsabilidad limitada. 
al igual que aquéllas; o las relativas a sociedades anónimas, por asimilarlas a sociedades de capital; o, las de unas y otras por estimarlas sociedades que participan de los caracteres de ambas, caso que se cocich dichos caracteres complica con la tarea de discriminar concia con los y qué normas de unas y otras se aplican en correspondencia con los mismos. Por otra parte, ya se han advertido tales dificultades, a través de lo expuesto, y ellas surgen con más nitidez cuando, en través de entrarse a considerar diversos aspectos en que los estatutos legales son omisos o poco claros.

Pasando revista a las leyes especiales, encontramos que la arcentina aplicables a esta clase de sociedades las disposiciones del Código de Comercio y las del Código Civil que se conformen con su naturaleza jurídica y no hayan sido modificada por las disposiciones precedentes" (art. 24); esta indeterminación por las en ventajosa al permitir que se acuda a uno u otro según se trate de responsabilidad limitada se aproxime a un asioción resulta de la ley boliviana: "Se aplicarán a estas sociedades las demás leyes civiles o comerciales que no estén en oposición con su naturaleza jurídica y que no contraríen la presente ley" (art. 18).

En orientación diversa, las leyes uruguaya (art. 28), colombiana (art. 11) y chilena (art. 4. ${ }^{\circ}$ ) establecen como disposiciones supletorias las relativas a sociedades colectivas; la ley mexicana, su fós precisa, indica determinadas disposiciones sobre esta clase de sociedades, que son aplicables (art. 86). En cambio, la ley clase de sociedades, que son aplicables (art. brasileña (art. 18) prescribe que seran observada en cuante las disporegulado en la ley de sociedades anónimas ( ${ }^{38}$.

En el caso de la legislación peruana sobre la materia, inserta en el Código Civil, no cabe duda que rigen las normas generales sobre sociedades contenidas en este cuerpo de leyes. $Y$ en las que nada dicen - leyes de Paraguay y Cuba - el problema se hace más agudo.

En definitiva: es de particular importancia que las leyes especiales o capítulos que los códigos consagren a estas sociedades resulten lo más amplios y previsores posibles, y que, cuando sea necesario, remitan concretamente a otras disposiciones aplicables; se evitarían así un sinnúmero de cuestiones que pueden suscitarse en doctrina y jurisprudencia y ser apreciadas de manera dispar, con grave perjuicio para la correcta aplicación de las normas jurídicas

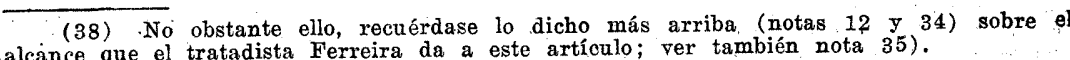

10. - Conclusiones. Cerramos aquí esta rápida revista de legislaciones latinoamericanas, en la cual nos hemos ceñido a la comparación escueta de éstas y a alguna breve referencia doctrinaria. Seduce, sin duda, un examen más amplio, pero con ello llegaríamos a proporciones incompatibles con este trabajo.

El método comparativo - usado aquí en una expresión simple - tiene en derecho mercantil una especial importancia, como lo señalaba hace poco el profesor Escarra. El derecho comercial comparado - dice entre otras cosas el aludido tratadista, en un reciente artículo $\left({ }^{39}\right)$ - goza de una ventaja esencial que es "la uniformidad relativa de los hombres y de las instituciones que constituyen sus objectos de estudio". Y señala más adelante como uno de los resultados más importantes de la ciencia comparativa en el campo de la política legislativa nacional y de la unificación internacional, el caso de las sociedades de responsabilidad limitada, institución de orígen germánico que "ha podido aclimatarse en numerosos países sin grandes dificultades, mientras que adaptaciones semejantes habrían sido inconcebibles en otros campos".

Las afirmaciones del conocido autor tiene su confirmación en lo aquí estudiado. aLs sociedades de responsabilidad limitada se han adaptado rápidamente a toda latinoamérica (con excepciones contadas, al escribir esto y de acuerdo con nuestra información actual) en un lapso de treinta años, que arranca de la sanción de la primera ley: la brasileña; y llegarán sin duda a una extensión total pues se trata de una institución que tiene grandes ventajas y que puede adaptarse $\sin$ dificultades respondiendo a modalidades fundamentalmente iguales.

Debemos aspirar ahora a una mayor perfección en las leyes estudiadas, las cuales, a nuestro entender, - y como ya lo dejamos entrever - pecan en general por incompletas, algunas con un excesivo laconismo como la chilena $\left({ }^{40}\right)$. Las compañias de responsabilidad limitada deben tener un estatuto prolijo - sin necesidad de llegar a un detallismo abrumador - que contemple y resuelva muchas cuestiones que, en mayor o menor número, exoluyen las leyes vigentes y obligan a dificultades de interpretación. El reenvío expresa o sobreentendido a normas que rigen otras sociedades como vimos en el capítulo anterior - no resuelve sino que acrecienta los problemas, por la dificultad primordial que nace del carácter

(39) Jean Escarra, El derecho comercial y el método comparativo, citado en la nota (1.) También puede incluirse en esta apreciación, entre otras, a la ley brasileña y así lo señala Oliveira e Silva en estos términos: "De paso (digamos) que el Decreto la ley portuguesa, de 1901 , regula la vida administrativa y fiscalizacion de la sociedad limitada, o su registro y disolución, además de la emisión de títulos de obligaciones, 
híbrido de las sociedades aludidas: participan de rasgos de sociedad de personas, lo que lleva a apilcar principios de las colectivas, y de sociedades de capital, semejanza que trae consigo la vigencia de lo relativo a sociedades anónimas; y entre ellas el deslinde se hace difícil. Eso no ocurriría - o sería en poca escala - de mediar una difícil. Eso no ocurriría - o sería en poca escala - de mediar una ya que hoy sólo existen leyes especiales muy posteriores a la sanción de los mismos o injertos en ellos; se excluye de este juicio, en cierta medida, el caso de México donde rige una ley general de sociedades:

Al mismo tiempo, es deseable una uniformidad entre nuestras legislaciones, que ya se advierte en buena medida en el caso de varias de ellas; las leyes argentina, uruguaya y paraguaya son sensiblemente iguales. La diversidad de orientación que existe en muhos aspectos, debe ceder paso en nuestros países, a una ley de carácter uniforme para las sociedades de responsabilidad limitada, por lo menos en los lineamientos generales. Naciones jóvenes, de legislaciones también jóvenes, ávidas de progreso y propensas a la jovenes, avidas de progeso y propensas a la se opongan a ésta y mayores conquistas en el campo del derecho positivo.

\section{RELATÓRIO E PARECER}

Relator: PAULO BARBOSA LESSA

1 - Apresenta o ilustrado titular da cadeira de Direito Comercial da tradicional Faculdade da Universidade de Santa Fé trabalho altamente fecundo. Diz, inicialmente, que seu esfôrço foi feito no afã de emprestar aos plasmadores da nova lei comercial brasileira um subsídio de estudo comparativo das legislações latino-americanas a respeito das sociedades por cotas de responsabilidade limitada. $\mathrm{E}$, nas suas conclusões, salienta: "Las sociedades de responsabilidad limitada se han adaptado rápidamente a toda latinoamérica en un lapso de treinta años, que arranca de la sanción de la primeira ley: la brasileña; y llegarán sin duda a una extensión total pues se trata de una institución que tiene grandes ventajas y que puede adaptarse $\sin$ dificultades respondiendo a modalidades fundamentalmente igua les." "Debemos aspirar ahora a una mayor perfección en las leyes estudiadas, las cuales pecan en general por incompletas, algunas con un excesivo laconismo." "Al mismo tiempo, es deseable una uniformidade entre nuestras legislaciones, que ya se advierte en buena medida en el caso de varias de ellas. La diversidad de orien- tación que existe en muchos aspectos, debe ceder paso en nuestros países, a una ley de carácter uniforme para las sociedades de responsabilidad limitada, por lo menos en los lineamentos generales. Naciones jóvenes, de legislaciones también jóvenes, ávidas de progreso y propensas a la unidad en todo sentido, no presentan divergencias irreductibles que se opongan a ésta y mayores conquistas en el campo del derecho positivo".

2 - No sentido de corroborar, já o sentido de seu trabalho, já a viabilidade de suas conclusões, o mestre argentino produz excelentes considerações sôbre as generalidades do instituto, as características fundamentais da figura jurídica, tratando, a seguir, com segurança e brilho, os problemas da constituição, da publicidade, do número de sócios, do objeto, do capital, da razão social ou denominação, do govêrno, administração e fiscalização da sociedade, da sua dissolução e do direito subsidiário a ela aplicável. Como se nota à simples formulação dos problemas, ressalta a variada gama dos assuntos submetidos à análise, com resultados proveitosos.

3 - E notório o valor do método comparativo em direito. Já se salientou que remonta êle à "Política" de Aristóteles. Contudo, foi no século passado que o método apresentou em premissas de inegável valia. Assinalou-se que, sob pena de chegar-se a resultado improfícuo, necessário é que se faça o estudo comparativo mais do direito que das legislações, e que se tenha presente •o caudal de contribuição trazido para a compreensão do instituto pela análise do sistema do país em estudo, pela jurisprudência, pela prática contratual e pela técnica jurídica. Só assim se poderá aspirar a um objetivo cheio de realidades. Assim, presta o direito comparado inegável apoio ao estudioso: em primeiro lugar, porque lhe permite melhor compreender as premissas do próprio direito nacional ressaltadas no confronto com os vários sistemas; ao depois, porque torna possível a utilização das alheias experiências.

4 - Por tudo isso dissentimos do subtítulo da tese apresentada pelo professor argentino, só explicável pela modéstia de seu temperamento, aliás nìtidamente perceptível na missiva com que apresenta seu trabalho. Este não é puramente um estudo comparado das legislações latino-americanas. $\hat{E}$ mais, muito mais, porque traz, também, uma integração dêsses textos na realidade das várias doutrinas nacionais. Estuda o autor, em realidade, o sistema dos variados países, tirando conclusões de muita valia.

5 - No tocante ao nosso direito, o professor argentino se louva nas autoridades mais eminentes de nossa pátria. Salienta, assim, - nosso sistema em que a responsabilidade não se limita à quota trazida para o capital da sociedade, mas sim pelo próprio capital, gerando uma solidariedade até a sua integração. Estuda o nosso 
sistema de firma ou denominação para as sociedades de responsabilidade limitada. Sôbre a administração da sociedade, sôbre o direito de contrôle dos socios, e, ligeiramente, sôbre a dissolução. Dois pontos, entretanto, devem ser relatados com mais ênfase. $O$ primeiro reside na afirmação de que, em nosso direito, são as sociedades de responsabilidade limitada essencialmente mercantis. Em realidade não o são. A matéria mercantil é, em nosso país, nìtidamente marcada pelo objeto. Apenas em um ponto se dá prevalência à forma. Isso no terreno das sociedades anônimas, por expressa disposição de lei. Nas sociedades de responsabilidade limitada, assim não acontece no sentir dos melhores opinadores, e no da prática diuturna. Ao problema também se aplica a disposição exarada no código civil dizendo que a forma ûas sociedades mercantis não mercantiliza a sociedade, que civil permanece, desde que o objeto seja civil. O segundo problema digno de nota é a percepção nítida do mestre argentino sôbre as dificuldades de interpretação de nossa lei, a respeito do direito supletório a respeito das sociedades de responsabilidade limitada. A tal ponto que êle caracteriza êsse ponto como um dos que mais reclama pronta e clara solução.

6 - Essas rápidas considerações permitem se aceitem as conclusões do mestre da Faculdade do Litoral. É em realidade anseio de todos os estudiosos do direito a aproximação das normas jurídicas dos povos, a fim de que traduzam elas, tanto quanto possível, a identidade de princípios que norteiam as condutas humanas, em todos os pontos do planêta. Por outro lado é, realmente, de desejar que a lei reguladora das sociedades de responsabilidade limitada seja um tanto completa, a fim de resolver muitas das dúvidas que têm dificultado a sua prática.

7 - Por êsses motivos, sou de parecer que a Comissão dê a sua aprovação ao trabalho do mestre argentino, considerando-o como valioso subsídio para a melhoria das legislações internas dos países americanos e digno da atenção de Conferência internacional que porventura se reúna a fím de tratar do problema da unificação das normas de direito dos vários países latino-americanos.

\section{BRUNO MENDONGA LIMA} PAULO BARBOSA LESSA

Discutido e Aprovado o relatório e recomendada a sua aprovação ao plenário.

Pôrto Alegre, 17 de Agôsto de 1950

ANTÖNIO MARTINS FILHO

JOSÉ BAPTISTA NETO

\section{DEBATES EM PLENÁRIO}

O SR. PRESIDENTE - Júlio César Bonazzola - Vamos submeter à discussão a tese intitulada "Sociedades por responsabilidade limitada". E relator o dr. Barbosa Lessa.

O SR. PAULO BARBOSA LESSA - Exmo. Senhor Presidente. Senhores Congressistas.

Esta tese é intitulada "Sociedades por responsabilidade limitada". Antes de iniciar o relatório da mesma, desejo ressaltar um pequeno. pormenor que, aliás, se reveste de grande importância. A tese é realmente uma das mais valiosas apresentadas a êste Congresso e havia sido distribuída, para relatório, ao eminente professor desta $\mathrm{Fa}$ culdade, senhor Ernani Estrella, meus mestre, a quem devo boa parte da minha formação jurídica. Lamentàvelmente, contudo, o eminente professor enfermou e, desta forma, foi feita sua substituição, à última hora, o que, evidentemente não poderia dar muito bom resultado. (Não apoiados.)

Vou passar a ler o relatório da tese.

\section{(LÊ O RELATÓRIO)}

Este parecer foi discutido e aprovado pela Comissão, que recomenda a sua aceitação pelo plenário. (Palmas.)

O SR. PRESIDENTE - Submeto à consideração dos presentes a tese que acaba de ser versada. (Pausa.) Se não houver objeções, vou considerá-la aprovada. (Pausa.) Aprovada. (Palmas.) 


\section{LIMITAÇÃO DA RESPONSABILIDADE DO COMERCIANTE INDIVIDUAL}

\section{Antônio Martins Filho}

Professor Catedrático de Direito Comercial da Facul-

dade de Direito do Ceará, Catedrático de Economia
Política da Faculdade de Ciências Economicas.

\section{T E S E}

A emprêsa individual de responsabilidade limitada, constituindo a última fase do processo evolutivo da limitação dos riscos, é insistentemente reclamada pelos agentes da atividade econômica dos novos tempos.

Recusando-a de direito, não evitará o legislador a existência de fato dêsse tipo de emprêsa, que passa a funcionar sob forma de sociedade fictícia ou unipessoal.

Dada a importância e complexidade de que o instituto se rereste - e atendendo a que se trata de problema de ordem técnica - impõe-se o seu estudo e discussão em maior amplitude, para que se Aecida sôbre a conveniência ou inoportunidade de sua inclusão no novo Código Mercantil.

\section{I S C U S S ̃̃ O}

\section{I - CONSIDERAÇÕES PRELIMINARES}

a) Nova codificação do Direito Comercial

1 - A conveniência de uma revisão periódica dos códigos constitui matéria que, pela sua próprio natureza, não pode comportar contestação. Decorre da circunstância de que as leis, tal qual os indivíduos a que se destinam servir, sofrem também a ação incoercível do tempo. E desde que lhes falta o atributo da imutabilidade, terão necessàriamente de se ajustar aos novos imperativos sociais, resultantes da lei da evolução.
2 - Essa a situação em que ora se encontra o Código Comercial brasileiro.

Promulgado em 1850, quando a atividade mercantil estava imensamente distanciada do gráu de intensidade que hoje a caracteriza, é natural que o secular Estatuto não mais satisfaça às exigências dos dias presentes.

Falhas e lacunas se foram tornando evidentes, sendo em parte remediadas com o aparecimento de leis novas, algumas sucessivamente modificadas. Em conseqüência disso, as linhas estruturais do velho Código, perdendo a sua feição primitiva, apresentam, hoje, profundas e justificáveis mutilações.

Com efeito, o século que lhe assinala a eficácia foi precisamente aquêle em que se fizeram sentir, de maneira a mais decisiva, a influência da máquina no âmbito dos negócios, o aperfeiçoamento e especialização da técnica, a hegemonia do crédito em relação à economia monetária, o advento da aeronavegação, isto é, o aparecimento de um mundo novo, dinâmico, e complexo para as atividades industrial e mercantil.

3 - Ressaltando, embora, a necessidade de uma nova codificação do nosso Direito Comercial, contudo é mister frisar que não se trata de tarefa fácil ou de simples concretização.

Comprova a veracidade dessa afirmativa a circunstância de já se haver iniciado algumas tentativas neste sentido, a começar pelo Projeto Inglês de Souza, que data de 1912.

Preconizando a unificação do direito privado - idéia que posteriormente perdeu a sua intensidade, em virtude da promulgação do Código Civil - o projeto do insigne comercialista ainda conseguiu subir ao Senado, sendo ali confiado ao estudo de uma Comissão Especial.

A abundância de emendas e correções, a par do expurgo de tôda a matéria de direito civil, desvirtuaram a tentativa de codificação de Inglês de Sousa, daí se originando o chamado Projeto do Senado, remetido à Câmara dos Deputados, em 1927.

Dois anos depois, eis que surge o Substitutivo do Desembargador Vieira Ferreira, o qual, apesar de oferecer algumas melhorias em relação aos trabalhos até então realizados, ainda não logrou solucionar o problema em equação.

4 - No período de restrições constitucionais, que vai de 1930 até 1945 - com ligeiro interregno resultante da Constituição de 1934 - nada ou quase nada se conseguiu efetivar em favor do novo Código, se bem que se tratasse de uma época sobremodo propícia à elaboração de um trabalho dêsse gênero.

5 - Reconstitucionalizado o país e ocorrendo a circunstância favorável de se encontrar como detentor da Pasta da Justiça um 19 - R. D. $10^{\circ}$ Vol. 